\title{
Relative importance of professional practice and engineering management competencies
}

\author{
Dirk Pons \\ University of Canterbury, New Zealand. Email: dirk.pons@canterbury.ac.nz
}

Preprint of published paper. Citation: Pons, D. J. (2015). "Relative importance of professional practice and engineering management competencies." European Journal of Engineering Education 10.1080/03043797.2015.1095164. DOI: http://dx.doi.org/10.1080/03043797.2015.1095164

\begin{abstract}
Problem- The professional practice of engineering always involves engineering management, but it is difficult to know what specifically to include in the undergraduate curriculum. Approach-The population of New Zealand practising engineers was surveyed to determine the importance they placed on specific professional practice and engineering management competencies. Findings- Results show that Communication and Project planning were the two most important topics, followed by others as identified. The context in which practitioners use communication skills was found to be primarily with project management, with secondary contexts identified. The necessity for engineers to develop the ability to use multiple soft skills in an integrative manner is strongly supported by the data. Originality- This paper is one of only a few large-scale surveys of practising engineers to have explored the soft-skill attributes. It makes a didactic contribution of providing a ranked list of topics which can be used for designing the curriculum and prioritising teaching effort, which has not previously been achieved. It yields the new insight that combinations of topics are sometimes more important than individual topics.
\end{abstract}

Keywords: engineering management; professional practice; graduate attributes; Washington Accord; project management; curriculum; syllabus; communication

\section{Introduction}

One of the defining characteristics of an engineering degree is that it teaches the student to apply mathematics and a range of engineering sciences to the solution of technology problems. However these problems are embedded in a soft context: they are solved by teams of people working economically in organisations, and the reason to solve them is to add value to a client, customer, or society. Hence there is a need for graduates to have skills in the management of people and organisations and to create technological solutions that are aligned to society's needs. Furthermore a natural career path for practising engineers is to progress into management of engineering ventures [1]. Thus the engineering profession absolutely expects the inclusion of professional-practice and engineering-management skills within a professional engineering degree. An international collaboration exists between the individual national professional bodies, in the form of the International Engineering Alliance (IEA). Thus the profession has developed an internationally consistent set of expectations of the professional content of an engineering education. These are expressed in the 
Washington-, Sydney-, and Dublin-Accord for professional engineering, engineering technology, and technician engineering respectively [2]. The graduate attributes of the Washington Accord (WA) are shown in Table 1. The profession then actively checks, through the accreditation process, that this does occur.

That undergraduates need to develop knowledge and skills in professional practice and engineering management is therefore not in question. The difficulty is that the Accords are worded in general rather than specific terms, e.g. environment \& sustainability, ethics, team work, project management, finance, among others. These lists permit wide interpretation as to the breadth and depth of coverage of the various topics. Nor is there any indication of the relative importance of the various topics. These are issues because they results in a large amount of variability in the curricula of courses between institutions. For example some universities focus their course on finance (e.g. economics, accountancy, time value of money, cashflow, financial statements), and cover ethics in a single lecture. Others put the emphasis in totally different areas. Again, the amount of time devoted to the teaching of professional practice is highly variable. Consequently there is not the maturity of curriculum in this field as there is in the engineering sciences.

The jurisdiction under examination is New Zealand (NZ). The Institution of Professional Engineers NZ (IPENZ) is the only professional body for NZ and includes all practice areas. IPENZ implements the local accreditation processes [3], and largely follows the Washington Accord in its interpretation [4]. Consequently the various engineering universities in NZ all align their professional practice and engineering management curricula to the WA graduate attributes. Even so, they all do so in somewhat different ways, which are checked at the periodic accreditation visits. Any issues with the curriculum and teaching thereof have historically been merely minor, and no programme has lost accreditation because of material deficiencies in this area. Nonetheless there is ongoing interest between professional educators towards the harmonisation of curricula and the sharing of best practices in the teaching of professional practice and engineering management.

This paper helps address this problem by identifying the specific needs of professional engineering practitioners. In this context 'professional' refers primarily to the practitioner perspective, as opposed to that of the academics and professors. We report on an evidencebased approach to the determination of the professional practice and engineering management curriculum for undergraduates. Results from a large survey of practicing engineers were used to determine the relative importance of a variety of topics, singularly and in combinations of topics. From this we draw implications for teaching this subject. The results also permit a secondary question to be answered, which is to determine the context in which practitioners use communication skills.

\section{$2 \quad$ Existing literature}

The potential curriculum for professional practice is large, and it is difficult for educators to know what to include in a curriculum. What capabilities do students need to learn to be effective as practising professional engineers? What is the relative importance of the different topics? These are important questions for course design, and the literature identifies the many ways educators have approached this problem. 
There is widespread acknowledgement among the professional educators of this field that the subject can be difficult to teach. 'Can the unteachable be taught?' is how the problem of teaching professional skills and management to engineers has sometimes been framed [5], thereby conveying the desperation that can exist in this area. That may be a somewhat extreme position, but even a positivist perspective would acknowledge that management and leaderships skills are areas needing further development for engineering [6].

There are several factors that contribute to the difficult of teaching engineering management. First, the subject can be disliked by students because of their predilection for mathematically tractable subjects rather than broader, more socially engaged, business roles [7] [8]. That can apply to university faculty too [9]. Academics teaching the subject may lack relevant experience from commercial practice, and thus find it difficult to contextualise the delivery [10].

In response to these challenges, innovative educators have taken a variety of imaginative approaches for teaching management to engineers. These typically seek to raise student engagement by embedding the student into the context, for example by simulating a creative environment, e.g. creating a game or simulation around the learning [11-14], or putting the student into a project-based environment [15-17].

Second, and the focus area of this paper, is the difficulty in knowing what to include in the curriculum. This curriculum issue is long-standing. Decades ago the need was anticipated for curriculum that would enable 'transition of the engineer from a technical specialist to an engineering management generalist who will constitute the large majority of future professional engineers' [18], and that need has never really abated [19]. It has been observed that undergraduate education primarily trained engineers for research \& development (R\&D) and academic positions, whereas most graduates went into management related areas with time [20]. The inadequacies of the curriculum in this regard have been pointed out [10,21,22], yet the criticism appears as fresh today as then. It has variously been asserted that the teaching of engineering management has been superficial, misguided, and lacking in relevance $[23,24]$.

The reality is that progress in defining a sufficient curriculum has been slow: much slower than in the engineering sciences. The profession continues to assert the relevance of softskills and engineering management, but it has been difficult to achieve a common expectation of what such a curriculum would contain. There are many potential topics that could be included, and it is difficult for lecturers to know which are the more important. Consequently the engineering management curriculum is generally based on local preferences and individual understanding of the issues.

\section{High-level graduate attributes}

The overall graduate attributes for an engineer are well-known, albeit at a broad abstract level, having emerged as an international consensus though the International Engineering Alliance [2]. Many countries, represented by their professional engineering institutions, are signatories to this Accord, and others are the in process of joining. 
The Washington Accord covers the requirements for a professional engineering degree and is most relevant to the present paper. It specifies twelve graduate attributes [2], see Table 1. Two are focussed on the engineering sciences: fundamental engineering knowledge, and investigation. Three attributes are focussed on solving complex problems: problem analysis; design of solutions; modern tool usage. These also tacitly include the human dimension because 'complex' problems are defined as resulting 'from interactions between wideranging or conflicting technical, engineering or other issues'. The remaining seven attributes are of a professional nature: responsibilities to society (includes health \& safety, legal, cultural); environment and sustainability; ethics; individual and team work; communication; project management and finance; life-long learning. In the past the following additional graduate competencies were explicitly required, but dropped from later versions: risk management, business practices, change management [25]. We mention this because our survey checked for the importance of these too. In some jurisdictions the Washington Accord requirements are re-packaged, and additional specifics and prescriptions are added in. These then become the national expectations against which accreditation is undertaken in that jurisdiction. A case is point is the USA, where the WA is reinterpreted into the ABET requirements [26]. However it is important to note that such local arrangements are derivative products and the Washington Accord remains the higher level reference standard. Other jurisdictions adopt the WA in its entirety, in which case the issue of potential misalignment does not arise.

\begin{tabular}{|c|c|c|}
\hline & & GRADUATE ATTRIBUTES for Washington Accord degree (paraphrased) \\
\hline 1. & $\begin{array}{l}\text { Engineering Knowledge : Breadth and depth of } \\
\text { education and type of knowledge, both } \\
\text { theoretical and practical. }\end{array}$ & $\begin{array}{l}\text { Knowledge: Have a systematic, theory-based understanding of the } \\
\text { natural sciences, conceptually-based mathematics, mathematical } \\
\text { methods, numerical analysis, statistics, computer and information science, } \\
\text { engineering fundamentals, engineering specialist knowledge, and } \\
\text { accepted practices. This knowledge is expected to cover the discipline as } \\
\text { a whole (as opposed to being limited to a sub-discipline), and much of it is } \\
\text { expected to be at the forefront of the discipline. } \\
\text { Apply this knowledge to the analysis, modelling, and solution of complex } \\
\text { engineering problems. }\end{array}$ \\
\hline 2. & Problem Analysis: Complexity of analysis & $\begin{array}{l}\text { Identify, formulate, research literature and analyse complex engineering } \\
\text { problems reaching substantiated conclusions using first principles of } \\
\text { mathematics, natural sciences and engineering sciences. }\end{array}$ \\
\hline 3. & $\begin{array}{l}\text { Design/ development of solutions: Breadth } \\
\text { and uniqueness of engineering problems i.e. the } \\
\text { extent to which problems are original and to } \\
\text { which solutions have previously been identified } \\
\text { or codified }\end{array}$ & $\begin{array}{l}\text { Design solutions for complex engineering problems and design systems, } \\
\text { components or processes that meet specified needs with appropriate } \\
\text { consideration for public health and safety, cultural, societal, and } \\
\text { environmental considerations. }\end{array}$ \\
\hline 4. & $\begin{array}{l}\text { Investigation: Breadth and depth of } \\
\text { investigation and experimentation }\end{array}$ & $\begin{array}{l}\text { Conduct investigations of complex problems using research-based } \\
\text { knowledge (research literature) and research methods including design of } \\
\text { experiments, analysis and interpretation of data, and synthesis of } \\
\text { information to provide valid conclusions. }\end{array}$ \\
\hline 5. & $\begin{array}{l}\text { Modern Tool Usage: Level of understanding of } \\
\text { the appropriateness of the tool }\end{array}$ & $\begin{array}{l}\text { Create, select and apply appropriate techniques, resources, and modern } \\
\text { engineering and IT tools, including prediction and modelling, to complex } \\
\text { engineering activities, with an understanding of the limitations. }\end{array}$ \\
\hline 6. & $\begin{array}{l}\text { The Engineer and Society: Level of knowledge } \\
\text { and } \\
\text { responsibility }\end{array}$ & $\begin{array}{l}\text { Comprehend the role of engineering in society and identified issues in } \\
\text { engineering practice in the discipline: ethics and the professional } \\
\text { responsibility of an engineer to public safety; the impacts of engineering } \\
\text { activity: economic, social, cultural, environmental and sustainability } \\
\text { Apply reasoning informed by contextual knowledge to assess societal, } \\
\text { health, safety, legal and cultural issues and the consequent responsibilities } \\
\text { relevant to professional engineering practice and solutions to complex } \\
\text { engineering problems. }\end{array}$ \\
\hline 7. & $\begin{array}{l}\text { Environment and Sustainability: Type of } \\
\text { solutions. }\end{array}$ & $\begin{array}{l}\text { Understand and evaluate the sustainability and impact of professional } \\
\text { engineering work in the solution of complex engineering problems in } \\
\text { societal and environmental contexts. }\end{array}$ \\
\hline
\end{tabular}




\begin{tabular}{|l|l|l|}
\hline 8. & Ethics: Understanding and level of practice & $\begin{array}{l}\text { Apply ethical principles and commit to professional ethics and } \\
\text { responsibilities and norms of engineering practice. }\end{array}$ \\
\hline 9. & $\begin{array}{l}\text { Individual and Team work : Role in and } \\
\text { diversity of team }\end{array}$ & $\begin{array}{l}\text { Function effectively as an individual, and as a member or leader in diverse } \\
\text { teams and in multi-disciplinary settings. }\end{array}$ \\
\hline 10. & $\begin{array}{l}\text { Communication : Level of communication } \\
\text { according to type of activities performed }\end{array}$ & $\begin{array}{l}\text { Communicate effectively on complex engineering activities with the } \\
\text { engineering community and with society at large, such as being able to } \\
\text { comprehend and write effective reports and design documentation, make } \\
\text { effective presentations, and give and receive clear instructions. }\end{array}$ \\
\hline 11. & $\begin{array}{l}\text { Project Management and Finance: Level of } \\
\text { management required for differing types of } \\
\text { activity }\end{array}$ & $\begin{array}{l}\text { Demonstrate knowledge and understanding of engineering and } \\
\text { management principles and apply these to one's own work, as a member } \\
\text { and leader in a team, to manage projects and in multidisciplinary } \\
\text { environments. }\end{array}$ \\
\hline 12. & $\begin{array}{l}\text { Life long learning: Preparation for and depth of } \\
\text { continuing learning. }\end{array}$ & $\begin{array}{l}\text { Recognize the need for, and have the preparation and ability to engage in } \\
\text { independent and life-long learning in the broadest context of technological } \\
\text { change. }\end{array}$ \\
\hline
\end{tabular}

Table 1: Graduate competencies required for Engineers at the end of a 4yr study programme, as per the Washington Accord [2], paraphrased.

Thus the Accord specifies attributes - knowledge and skills - that a student is required to have at graduation. It does not specify how the university has to go about creating those attributes. Universities are required to demonstrate that their curriculum does develop the required graduate attributes, and this is achieved through an accreditation process. Therefore to the extent that the graduate attributes include professional practice and engineering management, the accreditation process will ensure that that there is sufficient content in any one degree programme. In Australia the requirement is for at least $10 \%$ of course content in management related subjects [27]. However in many other jurisdictions the volume is not prescribed.

\section{Curriculum topics}

As this shows, an engineering degree is expected to contain a significant content to support professional practice and engineering management. However the Accords do not provide specific guidance for design of courses. For example, the Accord requires graduates to have some knowledge about 'finance', but does not say which of the many topics within that body of knowledge are more important. It is therefore left to the individual university and its lecturers to interpret and implement. Also, the Accord covers all the engineering disciplines, civil, mechanical, etc., and within those there are yet more specialised areas, but the Accord is unclear about the needs of specific industry [28].

Consequently each institution develops its own interpretation of what is required in the way of curriculum. There are many reports in the literature documenting what specific institutions decided to include in their curricula [16, 17, 29-32]. Generally these are reports of local teaching experiences and are therefore of a case-study nature. Typically these express statements by protagonists of current practice or future intent. Only very occasionally is there explicit evidence that the perceptions of the profession have informed these curriculum developments. It is also relevant to note that designing a new curriculum effectively imposes an 'intervention' in the educational experience of the students, yet the vast majority of cases in the literature have no measure of the efficacy of the intervention. Consequently while there is a profuse literature on the types of content various institutions have included, the real efficacy of those interventions is difficult to evaluate, and this means that the internal validity is uncertain. It is also difficult to determine which unknown situational variables might have led the institution to structure and deliver its curriculum in 
that particular way, and whether the experiences would reliably transfer to another institution. This means that the external validity is also uncertain. In most cases professional practice and engineering management are included as generic courses. Specialist undergraduate programmes for business engineering are comparably rare [33], which is understandable. Postgraduate programmes are common and there are numerous reports of the thinking behind these [30,34-46]. However the postgraduate information is of limited value since the rationale for the choice of subjects taught is seldom explicit. Nor have many sought accreditation [47]. This is in common with postgraduate programmes generally and therefore not a criticism, but it does mean that the alignment between these postgraduate programmes and the needs of the profession has invariably not been tested. Consequently the structure of postgraduate programmes is not a reliable guide to the content of undergraduate degrees.

Finding empirical data in this area is problematic, and in approaching the literature one has to appraise whether the insights are personal to the protagonists, or backed by data. The majority of the literature in this area is solely based on the speculative insights of the protagonists who developed the course, and while it is interesting to read what others thought about the problem facing them, the problems with internal and external validity reduce the applicability of the results. It is not surprising that many of these reports are of a conference nature, which incidentally also makes them harder to procure. Therefore the most useful papers in the literature are those that are evidence-based. This component of the literature suggests the following engineering management skills are important:

- Adaptable problem-solving, creativity [11], critical thinking [48], decision making skills [48].

- Systems thinking approaches [49], integrative skills [50], a wide perspective of engineering [49], and a multidisciplinary approach [51-53].

- Engineering economics [54].

- Project management [48] [49],

- Quality [49],

- Marketing [55],

- Teamwork [48], leadership [6, 48].

- Ethical and social responsibility [56].

- Communication stands out as a particular need [15, 41, 47, 57, 58].

More recently there has been an effort to define an examination curriculum [59], the list of which includes market research, strategic planning and change management, product manufacturability, project management, scheduling, total quality, procurement, accounting, engineering economics, supply chain, marketing, organisational structures, leadership, human resources, standards, intellectual property, ethics, and liability.

Lists are useful, but still have several limitations.

1. Most of these lists are of the type 'we need more of $x x x$ than is currently taught', but the difficulty is that the baseline is unknown, so the extent cannot be calibrated.

2. There is a problem of lack of specificity, since the lists cover a wide range of diverse topics. An associated problem is that the lists do not describe how deeply any one topic should be taught. For example, 'change management' is a vast topic in its own right, which could consume a whole course. It also has different meanings in various 
areas, e.g. in product design \& production it can refer to version control, whereas in business processes it involves changing the organisational culture and hence people's attitudes.

3. While the lists identify topics (e.g. 'communication'), they do not address the problem of how to contextualise the topics to students.

4. There is a lack of integration, in that the lists treat the topics as independent entities. Instead it is reasonable to expect that the topics could be clustered, but those associations are unknown. This is important because otherwise a curriculum risks being merely a disparate string of topics, when what we really want from a didactic perspective is to create in the graduate an integrated set of skills that can be applied to solve complex problems. Complex problems are those with many internal dependencies, and are not amenable to simplistic piecemeal solution approaches.

Most of the information in the literature is from the perspective of the academic institutions. There is a scarcity of empirical data from the engineering profession itself. Consequently there is a need for more empirical data from practising engineering, to help inform the design of the curriculum for professional practice and engineering management.

\section{Purpose and approach}

The purpose of the present work was to determine what practising professional engineers in industry felt were important engineering management topics to teach to students. This is worth doing because there is much confusion in the literature about which topics belong in the canon. There is a surfeit of opinion and a corresponding lack of objective evidence, and the voice of practising engineers is not heard often. Therefore this work aimed to undertake a broad inquiry to determine the relative importance of the many topics that people claim are important, rather than a specific analysis of individual topics. All the same, the results do permit a degree of more specific analysis, as will be shown for the 'communication' topic.

A questionnaire survey methodology was used, followed by statistical analysis. The survey addressed the entire New Zealand population of professional engineers, namely those who were members of IPENZ. The population was all the IPENZ Graduate Members, Professional Members, Technical Members, Associate Members and Fellows who were living in NZ and not-retired.

Two questions regarding engineering management were put to all members as part of an annual on-line salary survey run by IPENZ in 2009. The study was constrained to only two questions, because of concern about survey fatigue.

The survey was designed to assess the extent to which engineers were currently involved in engineering management. This was by self-report. No attempt was made to define 'engineering management' since (a) the concept is self-evident at least in the NZ context, being a recognised curriculum content at tertiary education and a recognised competency area for professional registration, and (b) we did not wish to frame respondents perceptions of 'engineering management' to our own constructs. Instead, a second question provided a list of engineering management topics and asked respondents to select those that they felt were important. So the definition of 'engineering management' was tacitly enumerated in 
the second question. The list of topics was determined as an aggregate of the various topics described in the Washington Accord and mentioned in the journal literature. Items that others had previously identified as part of the engineering management or professional practice competencies were included, with the exception of topics that were specific to single disciplines.

The questions were as follow:

Q17 To what extent does your current role involve engineering management? Response categories: -1 = Did not answer; 1=Very Great Extent; 2=Great Extent; 3=Moderate Extent; 4=Slight Extent; 5=Not at all; 6=Do not know or not applicable

Q18 In your opinion, what engineering management topics (if any) should be taught to undergraduates? (Select as many as apply)

A large field of choices was given, see Table 2. Respondents were permitted to make multiple selections. However they were not asked to rank them, as this was potentially too difficult to achieve with any reliability, and could have added to the risk of ignoring the question. The actual performance of practitioners against the various management skills was not determined in this survey.

\begin{tabular}{|l|l|l|}
\hline & Description & Abbreviation \\
\hline 1 & Career planning & CareerPIn \\
\hline 2 & Business Processes in typical employer firms & BusProcess \\
\hline 3 & Personality Styles & Persnlty \\
\hline 4 & Development and management of Teams & TeamDev \\
\hline 5 & Motivational Leadership & MotivLead \\
\hline 6 & Professional relationship with society & Society \\
\hline 7 & $\begin{array}{l}\text { Cultural issues including Biculturalism, } \\
\text { Multiculturalism and Treaty. }\end{array}$ & Cultural \\
\hline 8 & Health and safety requirements. & H\&S \\
\hline 9 & Professional associations including IPENZ. & ProfMemb \\
\hline 10 & Ethics. & Ethic \\
\hline 11 & $\begin{array}{l}\text { Environment and Sustainability including } \\
\text { Resource Management Act }\end{array}$ & Enviro \\
\hline 12 & Project planning & PM_Plan \\
\hline 13 & Project monitoring & PM_Monit \\
\hline 14 & Communication including report writing. & Communic \\
\hline 15 & $\begin{array}{l}\text { Engineering relevant Finance and project } \\
\text { Costing methods }\end{array}$ & ProjCost \\
\hline 16 & Accounting principles & Account \\
\hline 17 & Economics & Econ \\
\hline 18 & Budgets, Profit and Loss Statement & Budget \\
\hline 19 & NPV, Capital, and Depreciation & NPV \\
\hline 20 & $\begin{array}{l}\text { Product Life cycle, R\&D stages, Innovation, } \\
\text { Creativity }\end{array}$ & Innov \\
\hline 21 & Risk Management, including SAA/SNZ HB & RiskMan \\
\hline & & \\
\hline
\end{tabular}




\begin{tabular}{|l|l|l|}
\hline & 436 & \\
\hline 22 & Change Management & ChangeMan \\
\hline 23 & $\begin{array}{l}\text { Engineering relevant law, Contracts, Product } \\
\text { liability }\end{array}$ & Law \\
\hline 24 & Quality, Organisational Systems & Quality \\
\hline 25 & Product certification & PrdCert \\
\hline 26 & Procurement. & Procure \\
\hline 27 & Contract administration. & Contract \\
\hline 28 & Human Resource Management & HR \\
\hline 29 & Organisational Structure & OrgStr \\
\hline 30 & $\begin{array}{l}\text { Knowledge Management, NDA, IP } \\
\text { Protection }\end{array}$ & KM \\
\hline 31 & Marketing & Market \\
\hline 32 & $\begin{array}{l}\text { Entrepreneurship, organisation formation } \\
\text { and growth }\end{array}$ & Entrep \\
\hline 33 & $\begin{array}{l}\text { Strategy, External forces, Mission, Vision, } \\
\text { Governance. }\end{array}$ & Strategy \\
\hline
\end{tabular}

Table 2: Response categories for Q18 in survey

While these were the only two questions that were asked, the analysis also had access to data from other questions that were part of the survey, including: qualification, years since graduation, practice area, job points, and demographics. Job points is an IPENZ measure of job complexity and is determined by aggregating responses to several questions. Included therein are questions about the level of responsibility for decision-making by the engineer. It therefore broadly measures complexity in professional practice. This additional data permitted a much deeper analysis than the two engineering management questions on their own.

The number of responses received was 2276 , representing a $38 \%$ return. This is a high response rate.

Statistical methods were used to summarise the data and extract implications. One such method was the determination of summaries of frequencies. These are based on the frequency with which a response was given. In some cases the results were categorised by variables such as practice area. In addition a data-mining method called association rules analysis (ARA) was also used, to explore the data and seek out hidden relationships in a retrospective manner. The latter is an uncommon research method, with no known instances of it being applied to this type of situation. A brief summary of ARA is provided below. The software tool used was Statistica.

\section{$4 \quad$ Results}

These results are for the entire cohort of engineers, and include a variety of disciplines (civil, mechanical, electrical, electronic, etc.) and practice areas. The results are presented for single topics, then for the more complex situation of combinations of topics, and finally for the 'communication' topic. 


\subsection{Topics by simple frequency}

The results are shown in Figure 1, ranked by the percent support for each topic.

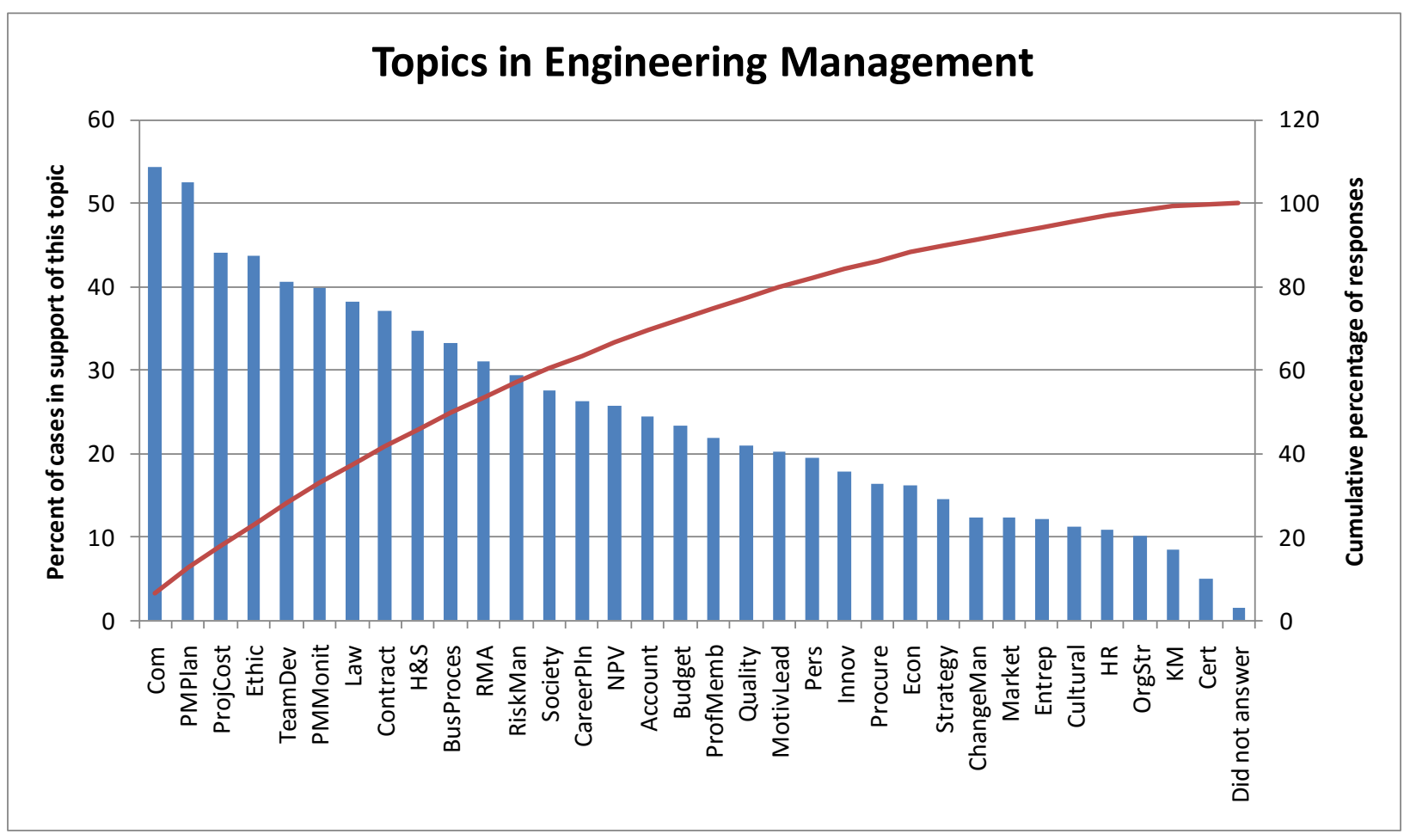

Figure 1: Support for various topics. Engineers felt that the most important topics were communication, closely followed by project planning, and then others as shown. For interpretation of the labels see Table 2.

This diagram shows several features. First, it identifies the most important topic as being COMMUNICATION, followed by PROJECT PLANNING. For a slightly wider set, all with at least 40\% support, add Project Costing, Ethics, and Team Development. It also shows the relative ranking of topics by their support. This is important from the lecturing perspective, as course designers must make difficult decisions on how much time to allocate to topics.

There is no scree feature (sharp change in support) visible in this plot, so there is no easy demarcation between topics that are relevant vs. irrelevant. Instead almost every topic offered was considered important by the profession, and nothing is eliminated outright. However there is a way to determine cut-off points, which is to use the cumulative line. Thus a portfolio of topics that covers $50 \%$ of the responses is: Communications, Project Planning, Project Costing, Ethics, Team Development, Project monitoring, Law, Contract, Health and Safety, and Business processes. For a 75\% portfolio add: Natural Resource management, Risk Management, Society, Career Planning, present value, Accounting, Budgets, and Professional Membership.

The analysis to this point is for single discrete topics. However this is a simplistic view as combinations of topics are sometimes more important than discrete topics, as the next analysis shows. 


\subsection{Combinations of Topics}

The more-detailed ARA showed that compound topics were often more important than individual topics on their own. Those results are shown in Appendix A, and summarised at a high level here. The list has been structured somewhat arbitrarily at $40 \%, 30 \%, 20 \%$ and $15 \%$ thresholds for support:

1. The top two EM topics from the perspective of engineering practitioners remain communication and project planning with support of $49 \%$ and $47 \%$ respectively.

2. The second tier of topics, all of which had at least $30 \%$ support, are (in descending order):

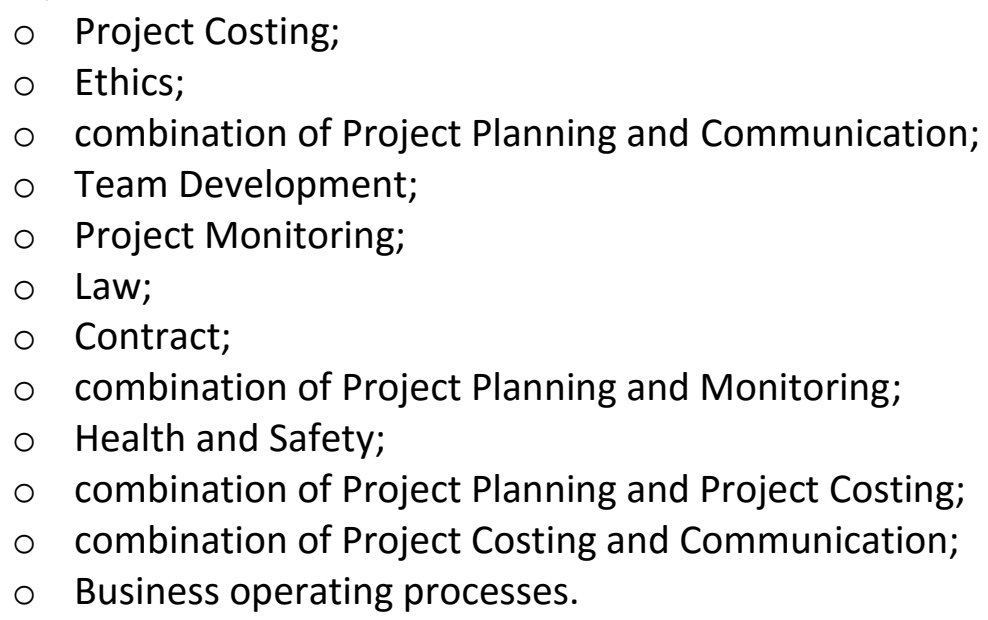

It is notable that finance and engineering economics do not feature in the top two tiers. This was somewhat surprising, given the high emphasis that many educators place on these topics. The third and fourth tier topics and combinations are shown in Appendix A and left for inspection. Thus it is possible to define a curriculum to various degrees of extensiveness, depending on how completely one wishes to cover the subject.

The presence of the combinations is potentially useful information for teaching purposes: it shows that there is commonality in how practicing engineers think of these topic clusters. Consequently it may be worth trying to teach them in similar contexts.

\subsection{What does the communication topic comprise?}

Communication emerges as the single most important topic. It encompasses many media (written, spoken), and the survey did not identify its specific subtopics. Unfortunately, it tends to be a subject that is difficult to teach [58] [60]. There are many voices in the literature attesting to the importance of communication skills for engineers [61] [62] [63] [64] [65] [66] [67] [68] [69] [70] [71] [72]. In some cases specific sub-sets of communication are addressed, such as collaboration [73], conflict resolution [74], or cross-cultural skills [75] [76]. However the limitation observed previously made applies: these report on university centric perspectives or intended changes to the content or way that communication skills are taught to students. In some cases, though rarely, the efficacy of the intervention has been validated. Examples include where student experiences have been evaluated, e.g. in capstone projects [77]. There appears to be no research in communication as grounded in the needs of the profession itself. 
Consequently it would be useful to identify from the profession itself (1) which parts of the larger body of communication to teach, (2) how to integrate the topic together and contextualise it for engineering, and (3) how to motivate students to want to excel at it. While the survey was not designed a priori to answer those questions, it is possible to extract some partial conclusions from the data.

The ARA method was used to extract all the topics associated with communication, as shown in Appendix A Table A3. In this analysis communication is the body, and the head identifies the associated topics. The table is ranked from greatest to least confidence, i.e. the association at the top are the more important. The table shown is only the communication sub-set of a larger table of rules. This table identifies the other topics close to communication. For example: Of those who identified communication as important, $75 \%$ also felt that project planning was important (rule 57). The head therefore identifies the context. Note that sometimes there are multiple heads, e.g. project planning and monitoring (rule 69), and that these may have greater confidence than single topics. Thus the combinations can be more important than the individual items. Next we categorised these contexts into clusters. We identified two main contexts:

1. Primary association: Communication is applied primarily in the context of project management (rules 57, 58, 62, 69, 66, 68, 67, 72, 70). Statistically, this context dominates for confidence, and has the most rules in support.

2. Secondary association: The second tier contexts for communication emerge as law and contract (rules 59, 61, 68, 67, 71), ethics (rules 65, 70), environment (rule 60), team development (rule 56), health and safety (rule 64), and risk management (rule 63).

Several implications emerge. First, these contexts can have very different communication requirements. For example health \& safety involves training, warning notices, instructions, safety culture, and compliance documentation, whereas team development involves roles and conflict. Thus communication emerges as a context-specific construct.

Second, some of these areas already specifically include communication within their body of knowledge. This is specifically for risk management and project management $[78,79]$. Those might be useful starting points for setting a communication syllabus for engineering. Or at very least the context in which communication is taught could be consistent with application into those areas.

Use of ARA therefore partially answers question (1): which parts of the larger body of communication to teach. The answer is: primarily those parts of communication that inform project management, and secondarily law, contract, ethics, environment, teams, health \& safety, and risk management.

The ARA also determines the reciprocal associations, see Appendix Table A4. In this analysis communication is the head, and the body identifies the associated topics. As an example, of those engineers who identified project planning, costing, and monitoring as important, $88 \%$ 
also selected communication (rule 148). The interpretation is that communication is essential if an engineer is going to be doing those three project activities. Thus an additional set of associations are uncovered from the other perspective. Most of these are common, e.g. rules 73 and 148, but note that the table emphasises the compound topics more, and we interpret these as practice areas where communication is particularly important. On this list the compound topics are more important (greater \% confidence) than single topics. For example project planning and ethics (rule 127) are more important than ethics on its own (rule 102). The presence of compound topics indicates complexity to the problem being addressed, i.e. engineers are integrating several skills in their practice. They are not just communicating ethically, but doing so along with project planning.

Specifically we identify two main categories of responses as:

1. Project management: whenever the project management activities are involved, in whatever combinations, there is a high chance that communication will also be required.

2. Miscellaneous areas: Activities such as environmental sustainability, law, contracts, risk management, health \& safety, ethics, and team development, all tended to also be associated with communication.

Association rules determine association, not causality. However within that limitation we interpret the above results to give a partial answer to question (2): how to contextualise 'communication' to engineering students. The answer is: show them that if they are to be successful at real engineering projects then they need to understand communication, because it's almost always needed in the project situation, and they are likely to be doing a lot of project work.

Regarding the other part of Question (2): how to integrate the selected components of communication so that they make for coherence, there are no complete answers yet. However there are frameworks in other disciplines that accomplish similar objectives. In particular the Project Management Institute (PMI) has developed a 'Body of Knowledge $(\mathrm{PMBOK})^{\prime}{ }^{\circledR}[78]$ that describes the activities that a professional project manager will generally have to consider. The first four knowledge areas (project integration, scope, time and cost) are core to project management (PM), whereas the others (cost, quality, human resources, communications, risk, and procurement) are from other disciplines. While this list does not cover all the topics required for the development of a Professional Engineer, it is notable just how much it does cover. If the only soft skills that undergraduate engineers were taught were the nine project knowledge areas, then that would be a reasonably good coverage. It is also relevant to note that many engineering graduates are involved in projectbased work. Naturally those graduates who move into general management are likely to need a wider set of management skills. We have not addressed Question (3): how to motivate students to want to excel at 'communication'. We leave that for future work. 


\section{Discussion}

\subsection{Originality}

This paper makes a contribution in several ways. First, it is one of only a few large-scale surveys of practising engineers to have explored the soft-skill attributes. Second, it makes a didactic contribution of providing a ranked list of topics which can be used for designing the curriculum and prioritising teaching effort, which has not previously existed in the literature. Interestingly, it shows that combinations of topics are sometimes more important than individual topics, and this too is a new insight. Third, it makes the methodological contribution of showing how the specific statistical method of association rules analysis may be used to extract insights about the EM curriculum. Fourth, it identifies the context in which Communication is important for engineers, which is primarily project management. Fifth, it identifies new interactions between the graduate attributes for professional engineers and the bodies of management in other areas like project management. This is important as many engineering ventures are conducted as projects, and it is useful to know which parts of project management thinking are particularly valuable in the broader setting of engineering management: project planning as it turns out.

\subsection{Implications}

Implications for curriculum development

The results readily suggest implications for setting curriculum. The most important topics are identified as Communications, Project Planning, Project Costing, Ethics, Team Development, Project monitoring, Law, Contract, Health and Safety, and Business processes. One can reasonably expect that a general engineering management course would at least cover those topics, though there may be discipline-specific variability. Furthermore, there were many cases where combinations of topics were more important than single topics. We interpret this as a need to understand and apply the topics in integrated ways rather than disjoint skills. This is consistent with the concept of engineering involving 'complex' tasks, as described in the Washington Accord. Thus an engineering programme that primarily interpreted engineering management as financial management and economics would be deficient according to the findings here.

It would have been convenient if the research had discovered that certain topics were essential, and others not. A limited set of topics would have permitted focussed attention for curriculum, and indeed accreditation. However this research did not find any such curtailed list. This is consistent with the observation that engineering involves complex problem-solving rather than simple deterministic approaches. As a tentative recommendation we suggest that any topic that has less than 15\% support in Figure 1 (or Table A1) is probably not relevant to a mandatory generic engineering management course.

A particularly far-reaching implication is the resourcing of delivery material. Existing textbooks are poorly focused on the topics identified here and more specifically targeted textbooks may be warranted. In many cases the focus is more on management than the engineering profession, which means that some topics are well-covered, but others not. For example, ethics and health \& safety seldom feature in management textbooks. However it should not be assumed that every topic needs to be taught in a specialised EM course: 
instead it may be possible to embed the learning elsewhere, including in other courses and in work experience [80].

\section{Implications for Graduate competencies and accreditation}

The Accords define a set of graduate competencies: knowledge and skills that students should have at graduation. These competencies represent the assessment of the engineering professional bodies, typically the aggregation of expert opinion through a committee process. The data presented here are from a different approach altogether, based on industry practitioner experience.

It is therefore possible to compare the topics across the Accords and the survey. This is potentially useful to determine level of support for the Accords, and to check for gaps. All the attributes of the Washington Accord [81] are identifiable in Table A1. However there are some other topics with higher frequency, which are not in the Accord. For example 'team development' and 'business processes' have high importance to the profession, and should probably be included in the graduate attributes.

While the survey only extended to New Zealand engineers, the results are likely to have relevance to other countries. This is because the IEM framework results in the engineering practices being comparable in the member countries. These include New Zealand, Australia, South Africa, Singapore and many countries in Europe and North America. Multi-national engineering consultancies exist across those countries, and there is a high level of international mobility within the engineering profession. So it is likely that the perspectives of the New Zealand engineers surveyed here are broadly representative of engineers in the IEM framework. In which case the implications for teaching practices, as identified above, could be generally relevant to other countries.

\section{Professional development for Professional Engineers}

Those practising Engineers who have a mind to professional development in the engineering management areas would be advised to focus their development on communication and project planning, as the survey results underline the importance of these topics to practising engineers. However these are only the basics, and engineers need to recognise that they will need to further develop their management skills from whatever based they obtained as undergraduates, by active professional development. The ability to apply multiple soft skills in an integrative manner is strongly supported by the data, and thus we presume that learning how to do this would also be advantageous.

\subsection{Limitations of this research}

There are several limitations to this work. First, the actual performance of graduates against the topics was not determined. It could be that graduates are already excellent at the topics, or they could be very bad: there is no way of knowing from these data.

Second, while the sample size and return rate were excellent for surveys, where $15 \%$ return is usually considered acceptable, the population of IPENZ members is skewed towards the civil and mechanical practice areas. The survey sample was from those engineers who have membership of IPENZ, but there are also other engineers who are not members of that body and therefore not sampled. Thus a different set of skills may be necessary for 
engineers who no longer maintain a professional membership. However this last point is a minor consideration as the focus of the present work is on identifying the skills needed by practising professional engineers, not those who have moved beyond the profession.

Third, the results are limited to identifying the relative importance of the various topics. While that partly addresses the question of what to include in a syllabus, it does not answer the question of how best to teach the material. For that a different design of research would be needed, one based on qualitative research methods.

\subsection{Implications for further research}

The present work aimed to undertake a broad inquiry to determine the relative importance of the many topics that people claim are important for engineers generally, rather than a specific analysis of individual topics. All the same, the results do permit a degree of more specific analysis, as was shown for the 'communication' topic. That it was possible to analyse the 'communication' topic this way was due to the statistical power (large survey dataset) and the novel application of a particular statistical method (association rules). It was not known beforehand which topics would be more or less important. For this reason and also to keep the survey simple and focussed on the broad picture, we did not ask detailed questions of the various individual topics. The results have now revealed the importance of the various topics. This presents an opportunity for future researchers to undertake more penetrating analyses of the various individual topics. However, there is also a warning for future researchers, since the current results show that combinations of topics can be more important that individual topics on their own, i.e. there is a degree of correlation or contextualisation to the topics. The information presented here, including the detailed statistical tables in the appendix, may help future researchers. They may be able to compare their results against those published here, and the contrasts and similarities could open new insights.

There are several strands of further research that could be followed:

- What do Professional Engineers understand as important within 'Communication', and how can that be included into curriculum? This is the most pressing. We have included some analysis here, but evidently there is more work to be done.

- Determine implications for continuous professional development of engineers.

- Find out the needs of specific engineering disciplines regarding engineering management topics, i.e. which topics are most important and to what depth they need to be taught.

- Determine how well-prepared graduates actually are, i.e. engineering management competence.

- Clarify what Engineers understand as important within 'project planning'. Is it Workbreakdown structure? Project costing? Gantt chart? Competent use of software? Workloads? Supporting Documents?

- Extend the research to other countries, and see to what extent the results are nationally-specific and why.

- Conduct a longitudinal study to determine whether the need for engineering management changes with career, when, and why. Explore how engineers' ranking of the importance of management topics changes over the span of their careers. 
Those who have moved into management roles, for example, may see finance and business strategy as of increasing importance.

- Compare teaching practices across several universities in a benchmarking study, and seek to identify best practices.

- For some engineers their career will take them out of engineering: they no longer apply their skills 'in' engineering but work 'with' their engineering skills in other settings. Further research could be valuable in exploring the skills needed by engineers for those non-engineering roles. For example, topics like strategy had relatively low support in this survey, but it may be that they are nonetheless important to the wider engineering population.

Finally, it is important to realise that there are at least three stakeholder groups who have an interest in the engineering management and professional practice canon. The first are the educational professionals. Their view tends to dominate the literature. The second is the engineering profession, which is less often heard in the literature, but exerts its influence through the accreditation process. The third is the student perspective. Relevant research questions for the latter group might be: what do they expect of their courses on this subject, what aspects of a professional engineering career do they perceive as particularly valuable to themselves, what motivates them about the professional practice subject? The present work has taken the practitioner perspective for its data, and used this to infer implications for educationalists. It has only peripherally addressed some of the student perspectives. There are many future research opportunities to examine this three-way integration.

\section{Conclusions}

The purpose of this project was to determine the curriculum topics for undergraduate education in engineering management. Practising engineers were surveyed. The overall results show that Communication and Project planning were the most important. However a large number of topics were identified as important to some extent: there was no clear cut-off observed for unimportant topics. For example the $50 \%$ portfolio is Communications, Project Planning, Project Costing, Ethics, Team Development, Project monitoring, Law, Contract, Health and Safety, and Business processes. Furthermore, there were many cases where combinations of topics were more important than single topics. We interpret this as a need of practitioners to understand and apply the topics in integrated ways rather than discrete disjoint skills. The results also identify the contexts for the various topics. It is shown that Communication is primarily associated with project management, and its secondary contexts are in law and contract, ethics, environment, team development, health and safety, and risk management.

Acknowledgements: We gratefully acknowledge the involvement of the Institution of Professional Engineers New Zealand (IPENZ) for provision of survey data, particularly Dr Andrew Cleland (CEO) and Brett Williams (Director - Learning and Assessment). IPENZ is the professional body which represents professional engineers from all disciplines in New Zealand (www.ipenz.org.nz). 


\section{Appendix A: Statistical tables}

The primary purpose of providing the detailed statistical tables is to provide comparative data for future studies and meta-analyses.

Table A1 shows the level of statistical support found for each topic, or combinations of topics. This table has data that may be useful for educationalists. The support can be understood to represent the proportion of engineers who believed that this topic, or combination of topics, was important. Hence higher support indicates a more important topic or set of topics. The results have been categorised by thresholds of $40 \%, 30 \%$, and $20 \%$. However these point are necessarily somewhat arbitrary. The table provides the data so that Readers can apply their own different selection criteria should they wish.

Table A2 shows the Correlation matrix for the various topics. The data may be useful to future researchers. primarily

Tables A3 and A4 provides the specific association rules for 'communication', first as the body and then as the head. The data are provided in support of the conclusions reached in the paper, and to support future research into this important topic. 


\section{Levels of support for topics and groups of topics}

\begin{tabular}{|c|c|c|}
\hline $\begin{array}{l}\text { Rule } \\
\text { number }\end{array}$ & Frequent itemsets & Support(\%) \\
\hline 12 & Communic & 48.92308 \\
\hline 4 & PM_Plan & 47.34066 \\
\hline 5 & ProjCost & 39.6044 \\
\hline 22 & Ethic & 39.2967 \\
\hline 42 & PM_Plan, Communic & 36.57143 \\
\hline 3 & TeamDev & 36.48352 \\
\hline 16 & PM_Monit & 35.86813 \\
\hline 8 & Law & 34.41758 \\
\hline 14 & Contract & 33.45055 \\
\hline 45 & PM_Plan, PM_Monit & 32.65934 \\
\hline 21 & $\mathrm{H} \& \mathrm{~S}$ & 31.34066 \\
\hline 36 & PM_Plan, ProjCost & 30.68132 \\
\hline 53 & ProjCost, Communic & 30.59341 \\
\hline 2 & BusProces & 30.02198 \\
\hline 80 & Communic, PM_Monit & 28.83516 \\
\hline 11 & Enviro & 27.95604 \\
\hline 119 & PM_Plan, Communic, PM_Monit & 27.25275 \\
\hline 63 & Law, Communic & 27.07692 \\
\hline 84 & Communic, Ethic & 26.9011 \\
\hline 44 & PM_Plan, Contract & 26.54945 \\
\hline 20 & RiskMan & 26.50549 \\
\hline 79 & Communic, Contract & 26.15385 \\
\hline 103 & PM_Plan, ProjCost, Communic & 25.97802 \\
\hline 38 & PM_Plan, Law & 25.89011 \\
\hline 49 & PM_Plan, Ethic & 25.75824 \\
\hline 56 & ProjCost, PM_Monit & 24.96703 \\
\hline 10 & Society & 24.74725 \\
\hline 51 & ProjCost, Law & 24.21978 \\
\hline 105 & PM_Plan, ProjCost, PM_Monit & 23.73626 \\
\hline 18 & CareerPIn & 23.69231 \\
\hline 31 & TeamDev, Communic & 23.38462 \\
\hline 28 & TeamDev, PM_Plan & 23.2967 \\
\hline 13 & NPV & 23.16484 \\
\hline 55 & ProjCost, Contract & 22.9011 \\
\hline 72 & Enviro, Communic & 22.50549 \\
\hline 85 & Contract, PM_Monit & 22.32967 \\
\hline 118 & PM_Plan, Communic, Contract & 22.32967 \\
\hline 109 & PM_Plan, Law, Communic & 22.28571 \\
\hline 83 & Communic, H\&S & 22.06593 \\
\hline 60 & ProjCost, Ethic & 22.02198 \\
\hline 6 & Account & 21.97802 \\
\hline 64 & Law, Contract & 21.75824 \\
\hline 134 & ProjCost, Communic, PM_Monit & 21.75824 \\
\hline 122 & PM_Plan, Communic, Ethic & 21.71429 \\
\hline 41 & PM_Plan, Enviro & 21.62637 \\
\hline 65 & Law, PM_Monit & 21.14286 \\
\hline 123 & PM_Plan, Contract, PM_Monit & 21.14286 \\
\hline 48 & PM_Plan, H\&S & 21.0989 \\
\hline
\end{tabular}




\begin{tabular}{|c|c|c|}
\hline $\begin{array}{l}\text { Rule } \\
\text { number }\end{array}$ & Frequent itemsets & Support(\%) \\
\hline 19 & Budget & 21.05495 \\
\hline 160 & PM_Plan, ProjCost, Communic, PM_Monit & 20.92308 \\
\hline 68 & Law, Ethic & 20.87912 \\
\hline 35 & TeamDev, Ethic & 20.74725 \\
\hline 47 & PM_Plan, RiskMan & 20.74725 \\
\hline 128 & ProjCost, Law, Communic & 20.65934 \\
\hline 93 & H\&S, Ethic & 20.52747 \\
\hline 82 & Communic, RiskMan & 20.35165 \\
\hline 101 & PM_Plan, ProjCost, Law & 20.35165 \\
\hline 111 & PM_Plan, Law, PM_Monit & 20.08791 \\
\hline 104 & PM_Plan, ProjCost, Contract & 20.04396 \\
\hline 29 & TeamDev, ProjCost & 20 \\
\hline 91 & PM_Monit, Ethic & 19.78022 \\
\hline 15 & ProfMemb & 19.73626 \\
\hline 52 & ProjCost, Enviro & 19.56044 \\
\hline 96 & TeamDev, PM_Plan, Communic & 19.56044 \\
\hline 133 & ProjCost, Communic, Contract & 19.34066 \\
\hline 77 & Enviro, Ethic & 19.20879 \\
\hline 59 & ProjCost, $\mathrm{H} \& \mathrm{~S}$ & 19.12088 \\
\hline 148 & Communic, Contract, PM_Monit & 19.12088 \\
\hline 88 & Contract, Ethic & 18.98901 \\
\hline 127 & PM_Plan, PM_Monit, Ethic & 18.94505 \\
\hline 9 & Quality & 18.9011 \\
\hline 108 & PM_Plan, ProjCost, Ethic & 18.9011 \\
\hline 114 & PM_Plan, Enviro, Communic & 18.9011 \\
\hline 137 & ProjCost, Communic, Ethic & 18.76923 \\
\hline 33 & TeamDev, PM_Monit & 18.72527 \\
\hline 142 & Law, Communic, PM_Monit & 18.59341 \\
\hline 26 & BusProces, Communic & 18.50549 \\
\hline 58 & ProjCost, RiskMan & 18.50549 \\
\hline 110 & PM_Plan, Law, Contract & 18.50549 \\
\hline 141 & Law, Communic, Contract & 18.50549 \\
\hline 167 & PM_Plan, Communic, Contract, PM_Monit & 18.46154 \\
\hline 78 & Communic, NPV & 18.28571 \\
\hline 155 & PM_Plan, ProjCost, Law, Communic & 18.28571 \\
\hline 24 & BusProces, PM_Plan & 18.06593 \\
\hline 66 & Law, RiskMan & 18.06593 \\
\hline 71 & Society, Ethic & 17.97802 \\
\hline 62 & Law, Enviro & 17.93407 \\
\hline 121 & PM_Plan, Communic, H\&S & 17.93407 \\
\hline 164 & PM_Plan, Law, Communic, PM_Monit & 17.89011 \\
\hline 43 & PM_Plan, NPV & 17.75824 \\
\hline 144 & Law, Communic, Ethic & 17.75824 \\
\hline 90 & PM_Monit, H\&S & 17.71429 \\
\hline 97 & TeamDev, PM_Plan, PM_Monit & 17.67033 \\
\hline 17 & Persnlty & 17.58242 \\
\hline 67 & Law, H\&S & 17.58242 \\
\hline 120 & PM_Plan, Communic, RiskMan & 17.58242 \\
\hline 159 & PM_Plan, ProjCost, Communic, Contract & 17.53846 \\
\hline 61 & Account, Communic & 17.49451 \\
\hline 25 & BusProces, ProjCost & 17.40659 \\
\hline 87 & Contract, $\mathrm{H} \& \mathrm{~S}$ & 17.40659 \\
\hline
\end{tabular}




\begin{tabular}{|c|c|c|}
\hline $\begin{array}{l}\text { Rule } \\
\text { number }\end{array}$ & Frequent itemsets & Support(\%) \\
\hline 151 & Communic, PM_Monit, Ethic & 17.27473 \\
\hline 95 & TeamDev, PM_Plan, ProjCost & 17.23077 \\
\hline 113 & PM_Plan, Law, Ethic & 17.23077 \\
\hline 138 & ProjCost, Contract, PM_Monit & 17.23077 \\
\hline 54 & ProjCost, NPV & 17.18681 \\
\hline 98 & TeamDev, ProjCost, Communic & 17.18681 \\
\hline 30 & TeamDev, Law & 17.0989 \\
\hline 32 & TeamDev, Contract & 17.0989 \\
\hline 70 & Society, Communic & 17.0989 \\
\hline 74 & Enviro, PM_Monit & 17.05495 \\
\hline 129 & ProjCost, Law, Contract & 16.96703 \\
\hline 89 & PM_Monit, RiskMan & 16.87912 \\
\hline 130 & ProjCost, Law, PM_Monit & 16.87912 \\
\hline 132 & ProjCost, Enviro, Communic & 16.87912 \\
\hline 92 & RiskMan, Ethic & 16.83516 \\
\hline 102 & PM_Plan, ProjCost, Enviro & 16.83516 \\
\hline 27 & BusProces, Ethic & 16.79121 \\
\hline 126 & PM_Plan, PM_Monit, H\&S & 16.74725 \\
\hline 162 & PM_Plan, ProjCost, Contract, PM_Monit & 16.74725 \\
\hline 168 & PM_Plan, Communic, PM_Monit, Ethic & 16.74725 \\
\hline 37 & PM_Plan, Account & 16.7033 \\
\hline 161 & PM_Plan, ProjCost, Communic, Ethic & 16.7033 \\
\hline 73 & Enviro, Contract & 16.65934 \\
\hline 107 & PM_Plan, ProjCost, H\&S & 16.61538 \\
\hline 34 & TeamDev, H\&S & 16.52747 \\
\hline 86 & Contract, RiskMan & 16.52747 \\
\hline 147 & Enviro, Communic, Ethic & 16.48352 \\
\hline 157 & PM_Plan, ProjCost, Law, PM_Monit & 16.43956 \\
\hline 136 & ProjCost, Communic, H\&S & 16.3956 \\
\hline 163 & PM_Plan, Law, Communic, Contract & 16.3956 \\
\hline 115 & PM_Plan, Enviro, PM_Monit & 16.35165 \\
\hline 124 & PM_Plan, Contract, Ethic & 16.35165 \\
\hline 81 & Communic, Budget & 16.30769 \\
\hline 145 & Law, Contract, PM_Monit & 16.13187 \\
\hline 125 & PM_Plan, PM_Monit, RiskMan & 16.08791 \\
\hline 149 & Communic, Contract, Ethic & 16.08791 \\
\hline 7 & Innov & 16.04396 \\
\hline 50 & ProjCost, Account & 16 \\
\hline 106 & PM_Plan, ProjCost, RiskMan & 16 \\
\hline 46 & PM_Plan, Budget & 15.91209 \\
\hline 76 & Enviro, $\mathrm{H} \& \mathrm{~S}$ & 15.91209 \\
\hline 99 & TeamDev, Communic, PM_Monit & 15.91209 \\
\hline 116 & PM_Plan, Enviro, Ethic & 15.91209 \\
\hline 131 & ProjCost, Law, Ethic & 15.82418 \\
\hline 57 & ProjCost, Budget & 15.78022 \\
\hline 69 & Quality, Communic & 15.78022 \\
\hline 23 & BusProces, TeamDev & 15.73626 \\
\hline 140 & Law, Enviro, Communic & 15.73626 \\
\hline 39 & PM_Plan, Quality & 15.69231 \\
\hline 40 & PM_Plan, Society & 15.64835 \\
\hline 135 & ProjCost, Communic, RiskMan & 15.56044 \\
\hline 146 & Enviro, Communic, PM_Monit & 15.47253 \\
\hline
\end{tabular}




\begin{tabular}{|l|l|l|}
\hline $\begin{array}{l}\text { Rule } \\
\text { number }\end{array}$ & Frequent itemsets & Support(\%) \\
\hline 170 & ProjCost, Law, Communic, PM_Monit & 15.47253 \\
\hline 94 & BusProces, PM_Plan, Communic & 15.42857 \\
\hline 112 & PM_Plan, Law, RiskMan & 15.42857 \\
\hline 166 & PM_Plan, Law, Contract, PM_Monit & 15.42857 \\
\hline 171 & ProjCost, Communic, Contract, PM_Monit & 15.42857 \\
\hline 117 & PM_Plan, Communic, NPV & 15.38462 \\
\hline 152 & Communic, H\&S, Ethic & 15.38462 \\
\hline 153 & TeamDev, PM_Plan, ProjCost, Communic & 15.38462 \\
\hline 156 & PM_Plan, ProjCost, Law, Contract & 15.34066 \\
\hline 139 & ProjCost, PM_Monit, Ethic & 15.25275 \\
\hline 154 & TeamDev, PM_Plan, Communic, PM_Monit & 15.25275 \\
\hline 150 & Communic, PM_Monit, H\&S & 15.20879 \\
\hline 169 & ProjCost, Law, Communic, Contract & 15.20879 \\
\hline 172 & PM_Plan, ProjCost, Law, Communic, PM_Monit & 15.16484 \\
\hline 75 & Enviro, RiskMan & 15.12088 \\
\hline 165 & PM_Plan, Law, Communic, Ethic & 15.12088 \\
\hline 173 & PM_Plan, ProjCost, Communic, Contract, PM_Monit & 15.12088 \\
\hline 100 & TeamDev, Communic, Ethic & 15.07692 \\
\hline 158 & PM_Plan, ProjCost, Enviro, Communic & 15.07692 \\
\hline 143 & Law, Communic, H\&S & 15.03297 \\
\hline
\end{tabular}

Table A1: ARA results for support greater than 15\%. Both single and compound topics are shown. The table is ranked by support level and the demarcations set at 40\%, 30\%, 20\%, and 15\%. Topics with less than 15\% support are not shown here at all.

\section{Correlation matrix}

\begin{tabular}{|c|c|c|c|c|c|c|c|c|c|c|}
\hline $\begin{array}{l}\text { Colum } \\
\mathrm{n}\end{array}$ & & $\begin{array}{l}\text { Col. } 4 \\
\text { Accou } \\
\text { nt }\end{array}$ & $\begin{array}{l}\text { Col. } 5 \\
\text { Budg } \\
\text { et }\end{array}$ & $\begin{array}{l}\text { Col. } 6 \\
\text { BusPr } \\
\text { oces }\end{array}$ & $\begin{array}{l}\text { Col. } 7 \\
\text { Caree } \\
\text { rPln }\end{array}$ & $\begin{array}{l}\text { Col. } 8 \\
\text { PrdCe } \\
\text { rt }\end{array}$ & $\begin{array}{l}\text { Col. } 9 \\
\text { Chan } \\
\text { geMa } \\
n\end{array}$ & $\begin{array}{l}\text { Col. } \\
10 \\
\text { Com } \\
\text { munic }\end{array}$ & $\begin{array}{l}\text { Col. } \\
11 \\
\text { Contr } \\
\text { act }\end{array}$ & $\begin{array}{l}\text { Col. } \\
12 \\
\text { Cultur } \\
\text { al }\end{array}$ \\
\hline 4 & Account & 1.00 & 0.47 & 0.21 & 0.15 & 0.20 & 0.27 & 0.33 & 0.31 & 0.17 \\
\hline 5 & Budget & 0.47 & 1.00 & 0.20 & 0.16 & 0.21 & 0.30 & 0.29 & 0.31 & 0.19 \\
\hline 6 & BusProces & 0.21 & 0.20 & 1.00 & 0.19 & 0.12 & 0.15 & 0.17 & 0.14 & 0.10 \\
\hline 7 & CareerPIn & 0.15 & 0.16 & 0.19 & 1.00 & 0.11 & 0.14 & 0.15 & 0.11 & 0.20 \\
\hline 8 & PrdCert & 0.20 & 0.21 & 0.12 & 0.11 & 1.00 & 0.25 & 0.15 & 0.17 & 0.21 \\
\hline 9 & Change Man & 0.27 & 0.30 & 0.15 & 0.14 & 0.25 & 1.00 & 0.20 & 0.22 & 0.18 \\
\hline 10 & Communic & 0.33 & 0.29 & 0.17 & 0.15 & 0.15 & 0.20 & 1.00 & 0.42 & 0.17 \\
\hline 11 & Contract & 0.31 & 0.31 & 0.14 & 0.11 & 0.17 & 0.22 & 0.42 & 1.00 & 0.16 \\
\hline 12 & Cultural & 0.17 & 0.19 & 0.10 & 0.20 & 0.21 & 0.18 & 0.17 & 0.16 & 1.00 \\
\hline 13 & Econ & 0.42 & 0.36 & 0.16 & 0.14 & 0.21 & 0.23 & 0.26 & 0.23 & 0.21 \\
\hline 14 & Entrep & 0.26 & 0.28 & 0.15 & 0.17 & 0.23 & 0.24 & 0.20 & 0.21 & 0.20 \\
\hline 15 & Ethics & 0.25 & 0.22 & 0.22 & 0.24 & 0.13 & 0.17 & 0.31 & 0.25 & 0.30 \\
\hline 16 & $\mathrm{H} \& \mathrm{~S}$ & 0.20 & 0.24 & 0.23 & 0.21 & 0.16 & 0.19 & 0.29 & 0.32 & 0.26 \\
\hline 17 & $\mathrm{HR}$ & 0.27 & 0.33 & 0.15 & 0.12 & 0.27 & 0.30 & 0.21 & 0.24 & 0.22 \\
\hline 18 & Innov & 0.30 & 0.33 & 0.17 & 0.16 & 0.22 & 0.27 & 0.29 & 0.25 & 0.22 \\
\hline 19 & KM & 0.27 & 0.29 & 0.18 & 0.17 & 0.31 & 0.33 & 0.20 & 0.21 & 0.28 \\
\hline 20 & Law & 0.33 & 0.33 & 0.18 & 0.15 & 0.19 & 0.25 & 0.43 & 0.46 & 0.22 \\
\hline 21 & Market & 0.29 & 0.32 & 0.18 & 0.17 & 0.23 & 0.28 & 0.24 & 0.24 & 0.20 \\
\hline 22 & MotivLead & 0.23 & 0.23 & 0.19 & 0.21 & 0.19 & 0.26 & 0.12 & 0.12 & 0.21 \\
\hline 23 & NPV & 0.39 & 0.48 & 0.18 & 0.13 & 0.16 & 0.29 & 0.33 & 0.32 & 0.18 \\
\hline 24 & OrgStr & 0.27 & 0.27 & 0.19 & 0.18 & 0.25 & 0.28 & 0.22 & 0.29 & 0.20 \\
\hline 25 & Persnlty & 0.17 & 0.17 & 0.22 & 0.23 & 0.17 & 0.21 & 0.14 & 0.10 & 0.25 \\
\hline 26 & PM_Monit & 0.29 & 0.33 & 0.18 & 0.15 & 0.18 & 0.25 & 0.47 & 0.46 & 0.13 \\
\hline 27 & PM_Plan & 0.30 & 0.29 & 0.17 & 0.15 & 0.16 & 0.23 & 0.54 & 0.45 & 0.14 \\
\hline 28 & Procure & 0.24 & 0.33 & 0.15 & 0.15 & 0.26 & 0.27 & 0.27 & 0.39 & 0.17 \\
\hline 29 & ProfMemb & 0.19 & 0.20 & 0.20 & 0.32 & 0.21 & 0.14 & 0.25 & 0.19 & 0.28 \\
\hline 30 & ProjCost & 0.36 & 0.37 & 0.25 & 0.12 & 0.19 & 0.24 & 0.46 & 0.42 & 0.18 \\
\hline 31 & Quality & 0.27 & 0.32 & 0.19 & 0.16 & 0.26 & 0.30 & 0.33 & 0.34 & 0.19 \\
\hline 32 & RiskMan & 0.28 & 0.30 & 0.16 & 0.15 & 0.17 & 0.28 & 0.33 & 0.37 & 0.22 \\
\hline
\end{tabular}




\begin{tabular}{|c|c|c|c|c|c|c|c|c|c|c|}
\hline 33 & Enviro & 0.27 & 0.27 & 0.16 & 0.17 & 0.14 & 0.21 & 0.39 & 0.35 & 0.32 \\
\hline 34 & Society & 0.17 & 0.15 & 0.18 & 0.28 & 0.17 & 0.11 & 0.23 & 0.14 & 0.35 \\
\hline 35 & Strategy & 0.26 & 0.27 & 0.17 & 0.16 & 0.23 & 0.32 & 0.20 & 0.19 & 0.22 \\
\hline 36 & TeamDev & 0.20 & 0.21 & 0.22 & 0.21 & 0.14 & 0.23 & 0.23 & 0.22 & 0.16 \\
\hline $\begin{array}{l}\text { Colum } \\
\mathrm{n}\end{array}$ & & $\begin{array}{l}\text { Col. } \\
13 \\
\text { Econ }\end{array}$ & $\begin{array}{l}\text { Col. } 14 \\
\text { Entrep }\end{array}$ & $\begin{array}{l}\text { Col. } \\
15 \\
\text { Ethic } \\
\text { S }\end{array}$ & $\begin{array}{l}\text { Col. } \\
16 \\
\text { H\&S }\end{array}$ & $\begin{array}{l}\text { Col. } 17 \\
\text { HR }\end{array}$ & $\begin{array}{l}\text { Col. } \\
18 \\
\text { Inno } \\
\mathrm{v} \\
\end{array}$ & $\begin{array}{l}\text { Col. } \\
19 \\
\text { KM }\end{array}$ & $\begin{array}{l}\text { Col. } 20 \\
\text { Law }\end{array}$ & $\begin{array}{l}\text { Col. } 21 \\
\text { Market }\end{array}$ \\
\hline 4 & Account & 0.42 & 0.26 & 0.25 & 0.20 & 0.27 & 0.30 & 0.27 & 0.33 & 0.29 \\
\hline 5 & Budget & 0.36 & 0.28 & 0.22 & 0.24 & 0.33 & 0.33 & 0.29 & 0.33 & 0.32 \\
\hline 6 & BusProces & 0.16 & 0.15 & 0.22 & 0.23 & 0.15 & 0.17 & 0.18 & 0.18 & 0.18 \\
\hline 7 & CareerPIn & 0.14 & 0.17 & 0.24 & 0.21 & 0.12 & 0.16 & 0.17 & 0.15 & 0.17 \\
\hline 8 & PrdCert & 0.21 & 0.23 & 0.13 & 0.16 & 0.27 & 0.22 & 0.31 & 0.19 & 0.23 \\
\hline 9 & ChangeMan & 0.23 & 0.24 & 0.17 & 0.19 & 0.30 & 0.27 & 0.33 & 0.25 & 0.28 \\
\hline 10 & Communic & 0.26 & 0.20 & 0.31 & 0.29 & 0.21 & 0.29 & 0.20 & 0.43 & 0.24 \\
\hline 11 & Contract & 0.23 & 0.21 & 0.25 & 0.32 & 0.24 & 0.25 & 0.21 & 0.46 & 0.24 \\
\hline 12 & Cultural & 0.21 & 0.20 & 0.30 & 0.26 & 0.22 & 0.22 & 0.28 & 0.22 & 0.20 \\
\hline 13 & Econ & 1.00 & 0.29 & 0.20 & 0.16 & 0.21 & 0.31 & 0.25 & 0.27 & 0.28 \\
\hline 14 & Entrep & 0.29 & 1.00 & 0.18 & 0.08 & 0.30 & 0.32 & 0.37 & 0.23 & 0.41 \\
\hline 15 & Ethics & 0.20 & 0.18 & 1.00 & 0.36 & 0.19 & 0.26 & 0.21 & 0.32 & 0.18 \\
\hline 16 & $\mathrm{H} \& \mathrm{~S}$ & 0.16 & 0.08 & 0.36 & 1.00 & 0.20 & 0.21 & 0.19 & 0.31 & 0.16 \\
\hline 17 & HR & 0.21 & 0.30 & 0.19 & 0.20 & 1.00 & 0.26 & 0.30 & 0.21 & 0.35 \\
\hline 18 & Innov & 0.31 & 0.32 & 0.26 & 0.21 & 0.26 & 1.00 & 0.37 & 0.31 & 0.30 \\
\hline 19 & KM & 0.25 & 0.37 & 0.21 & 0.19 & 0.30 & 0.37 & 1.00 & 0.27 & 0.35 \\
\hline 20 & Law & 0.27 & 0.23 & 0.32 & 0.31 & 0.21 & 0.31 & 0.27 & 1.00 & 0.24 \\
\hline 21 & Market & 0.28 & 0.41 & 0.18 & 0.16 & 0.35 & 0.30 & 0.35 & 0.24 & 1.00 \\
\hline 22 & MotivLead & 0.19 & 0.24 & 0.20 & 0.17 & 0.27 & 0.18 & 0.17 & 0.13 & 0.20 \\
\hline 23 & NPV & 0.35 & 0.30 & 0.27 & 0.27 & 0.24 & 0.42 & 0.27 & 0.34 & 0.27 \\
\hline 24 & OrgStr & 0.24 & 0.31 & 0.21 & 0.16 & 0.41 & 0.28 & 0.34 & 0.24 & 0.33 \\
\hline 25 & Persnlty & 0.20 & 0.19 & 0.23 & 0.19 & 0.20 & 0.18 & 0.18 & 0.11 & 0.19 \\
\hline 26 & PM_Monit & 0.23 & 0.19 & 0.24 & 0.29 & 0.22 & 0.27 & 0.23 & 0.39 & 0.23 \\
\hline 27 & PM_Plan & 0.25 & 0.19 & 0.29 & 0.27 & 0.21 & 0.30 & 0.22 & 0.40 & 0.22 \\
\hline 28 & Procure & 0.27 & 0.23 & 0.17 & 0.23 & 0.29 & 0.27 & 0.23 & 0.31 & 0.25 \\
\hline 29 & ProfMemb & 0.17 & 0.19 & 0.34 & 0.30 & 0.20 & 0.22 & 0.21 & 0.21 & 0.19 \\
\hline 30 & ProjCost & 0.30 & 0.22 & 0.27 & 0.30 & 0.21 & 0.34 & 0.24 & 0.46 & 0.24 \\
\hline 31 & Quality & 0.21 & 0.26 & 0.24 & 0.30 & 0.28 & 0.32 & 0.27 & 0.37 & 0.31 \\
\hline 32 & RiskMan & 0.28 & 0.20 & 0.30 & 0.32 & 0.26 & 0.35 & 0.25 & 0.43 & 0.20 \\
\hline
\end{tabular}

\begin{tabular}{|c|c|c|c|c|c|c|c|c|c|c|}
\hline $\begin{array}{l}\text { Colum } \\
n\end{array}$ & & $\begin{array}{l}\text { Col. } 22 \\
\text { Motiv } \\
\text { Lead }\end{array}$ & $\begin{array}{l}\text { Col. } \\
23 \\
\text { NPV }\end{array}$ & $\begin{array}{l}\text { Col. } 24 \\
\text { Org Str }\end{array}$ & $\begin{array}{l}\text { Col. } 25 \\
\text { Persnlt } \\
\mathrm{y}\end{array}$ & $\begin{array}{l}\text { Col. } 26 \\
\text { PM_M } \\
\text { onit }\end{array}$ & $\begin{array}{l}\text { Col. } 27 \\
\text { PM_PI } \\
\text { an }\end{array}$ & $\begin{array}{l}\text { Col. } 28 \\
\text { Procur } \\
\mathrm{e}\end{array}$ & $\begin{array}{l}\text { Col. } 29 \\
\text { Prof } \\
\text { Memb }\end{array}$ & $\begin{array}{l}\text { Col. } 30 \\
\text { Proj } \\
\text { Cost }\end{array}$ \\
\hline 4 & Account & 0.23 & 0.39 & 0.27 & 0.17 & 0.29 & 0.30 & 0.24 & 0.19 & 0.36 \\
\hline 5 & Budget & 0.23 & 0.48 & 0.27 & 0.17 & 0.33 & 0.29 & 0.33 & 0.20 & 0.37 \\
\hline 6 & BusProces & 0.19 & 0.18 & 0.19 & 0.22 & 0.18 & 0.17 & 0.15 & 0.20 & 0.25 \\
\hline 7 & CareerPIn & 0.21 & 0.13 & 0.18 & 0.23 & 0.15 & 0.15 & 0.15 & 0.32 & 0.12 \\
\hline 8 & PrdCert & 0.19 & 0.16 & 0.25 & 0.17 & 0.18 & 0.16 & 0.26 & 0.21 & 0.19 \\
\hline 9 & ChangeMan & 0.26 & 0.29 & 0.28 & 0.21 & 0.25 & 0.23 & 0.27 & 0.14 & 0.24 \\
\hline 10 & Communic & 0.12 & 0.33 & 0.22 & 0.14 & 0.47 & 0.54 & 0.27 & 0.25 & 0.46 \\
\hline 11 & Contract & 0.12 & 0.32 & 0.29 & 0.10 & 0.46 & 0.45 & 0.39 & 0.19 & 0.42 \\
\hline 12 & Cultural & 0.21 & 0.18 & 0.20 & 0.25 & 0.13 & 0.14 & 0.17 & 0.28 & 0.18 \\
\hline 13 & Econ & 0.19 & 0.35 & 0.24 & 0.20 & 0.23 & 0.25 & 0.27 & 0.17 & 0.30 \\
\hline 14 & Entrep & 0.24 & 0.30 & 0.31 & 0.19 & 0.19 & 0.19 & 0.23 & 0.19 & 0.22 \\
\hline 15 & Ethics & 0.20 & 0.27 & 0.21 & 0.23 & 0.24 & 0.29 & 0.17 & 0.34 & 0.27 \\
\hline 16 & $\mathrm{H} \& \mathrm{~S}$ & 0.17 & 0.27 & 0.16 & 0.19 & 0.29 & 0.27 & 0.23 & 0.30 & 0.30 \\
\hline 17 & $\mathrm{HR}$ & 0.27 & 0.24 & 0.41 & 0.20 & 0.22 & 0.21 & 0.29 & 0.20 & 0.21 \\
\hline 18 & Innov & 0.18 & 0.42 & 0.28 & 0.18 & 0.27 & 0.30 & 0.27 & 0.22 & 0.34 \\
\hline 19 & KM & 0.17 & 0.27 & 0.34 & 0.18 & 0.23 & 0.22 & 0.23 & 0.21 & 0.24 \\
\hline 20 & Law & 0.13 & 0.34 & 0.24 & 0.11 & 0.39 & 0.40 & 0.31 & 0.21 & 0.46 \\
\hline 21 & Market & 0.20 & 0.27 & 0.33 & 0.19 & 0.23 & 0.22 & 0.25 & 0.19 & 0.24 \\
\hline 22 & MotivLead & 1.00 & 0.17 & 0.25 & 0.33 & 0.16 & 0.15 & 0.19 & 0.21 & 0.16 \\
\hline 23 & NPV & 0.17 & 1.00 & 0.23 & 0.18 & 0.30 & 0.32 & 0.30 & 0.18 & 0.39 \\
\hline 24 & OrgStr & 0.25 & 0.23 & 1.00 & 0.23 & 0.23 & 0.24 & 0.30 & 0.21 & 0.25 \\
\hline 25 & Persnlty & 0.33 & 0.18 & 0.23 & 1.00 & 0.10 & 0.11 & 0.19 & 0.18 & 0.13 \\
\hline 26 & PM_Monit & 0.16 & 0.30 & 0.23 & 0.10 & 1.00 & 0.65 & 0.31 & 0.19 & 0.46 \\
\hline 27 & PM_Plan & 0.15 & 0.32 & 0.24 & 0.11 & 0.65 & 1.00 & 0.31 & 0.19 & 0.49 \\
\hline 28 & Procure & 0.19 & 0.30 & 0.30 & 0.19 & 0.31 & 0.31 & 1.00 & 0.17 & 0.31 \\
\hline 29 & ProfMemb & 0.21 & 0.18 & 0.21 & 0.18 & 0.19 & 0.19 & 0.17 & 1.00 & 0.20 \\
\hline
\end{tabular}




\begin{tabular}{|l|l|l|l|l|l|l|l|l|l|l|}
\hline 30 & ProjCost & 0.16 & 0.39 & 0.25 & 0.13 & 0.46 & 0.49 & 0.31 & 0.20 & 1.00 \\
\hline 31 & Quality & 0.19 & 0.28 & 0.33 & 0.15 & 0.37 & 0.35 & 0.31 & 0.22 & 0.33 \\
\hline 32 & RiskMan & 0.17 & 0.38 & 0.26 & 0.14 & 0.35 & 0.37 & 0.33 & 0.21 & 0.37 \\
\hline 33 & Enviro & 0.16 & 0.33 & 0.24 & 0.14 & 0.33 & 0.37 & 0.26 & 0.24 & 0.39 \\
\hline 34 & Society & 0.21 & 0.17 & 0.21 & 0.22 & 0.15 & 0.18 & 0.18 & 0.38 & 0.20 \\
\hline 35 & Strategy & 0.27 & 0.30 & 0.35 & 0.22 & 0.19 & 0.21 & 0.27 & 0.18 & 0.25 \\
\hline 36 & TeamDev & 0.40 & 0.21 & 0.21 & 0.29 & 0.24 & 0.25 & 0.22 & 0.23 & 0.24 \\
\hline
\end{tabular}

\begin{tabular}{|c|c|c|c|c|c|c|c|c|c|c|c|c|c|}
\hline $\begin{array}{l}\text { Colum } \\
\mathrm{n}\end{array}$ & & $\begin{array}{l}\text { Col. } 25 \\
\text { Persnlt } \\
\mathrm{y}\end{array}$ & $\begin{array}{l}\text { Col. } \\
26 \\
\text { PM_- } \\
\text { Moni } \\
\text { t }\end{array}$ & $\begin{array}{l}\text { Col. } 27 \\
\text { PM_PI } \\
\text { an }\end{array}$ & $\begin{array}{l}\text { Col. } \\
28 \\
\text { Proc } \\
\text { ure }\end{array}$ & $\begin{array}{l}\text { Col. } \\
29 \\
\text { Prof } \\
\mathrm{Me} \\
\mathrm{mb} \\
\end{array}$ & $\begin{array}{l}\text { Col. } 30 \\
\text { Proj } \\
\text { Cost }\end{array}$ & $\begin{array}{l}\text { Col. } \\
31 \\
\text { Quali } \\
\text { ty }\end{array}$ & $\begin{array}{l}\text { Col. } \\
32 \\
\text { Risk } \\
\text { Man }\end{array}$ & $\begin{array}{l}\text { Col. } \\
33 \\
\text { Envir } \\
0\end{array}$ & $\begin{array}{l}\text { Col. } \\
34 \\
\text { Socie } \\
\text { ty }\end{array}$ & $\begin{array}{l}\text { Col. } \\
35 \\
\text { Strat } \\
\text { egy }\end{array}$ & $\begin{array}{l}\text { Col. } \\
36 \\
\text { Team } \\
\text { Dev }\end{array}$ \\
\hline 4 & Account & 0.17 & 0.29 & 0.30 & 0.24 & 0.19 & 0.36 & 0.27 & 0.28 & 0.27 & 0.17 & 0.26 & 0.20 \\
\hline 5 & Budget & 0.17 & 0.33 & 0.29 & 0.33 & 0.20 & 0.37 & 0.32 & 0.30 & 0.27 & 0.15 & 0.27 & 0.21 \\
\hline 6 & BusProces & 0.22 & 0.18 & 0.17 & 0.15 & 0.20 & 0.25 & 0.19 & 0.16 & 0.16 & 0.18 & 0.17 & 0.22 \\
\hline 7 & CareerPIn & 0.23 & 0.15 & 0.15 & 0.15 & 0.32 & 0.12 & 0.16 & 0.15 & 0.17 & 0.28 & 0.16 & 0.21 \\
\hline 8 & PrdCert & 0.17 & 0.18 & 0.16 & 0.26 & 0.21 & 0.19 & 0.26 & 0.17 & 0.14 & 0.17 & 0.23 & 0.14 \\
\hline 9 & ChangeMan & 0.21 & 0.25 & 0.23 & 0.27 & 0.14 & 0.24 & 0.30 & 0.28 & 0.21 & 0.11 & 0.32 & 0.23 \\
\hline 10 & Communic & 0.14 & 0.47 & 0.54 & 0.27 & 0.25 & 0.46 & 0.33 & 0.33 & 0.39 & 0.23 & 0.20 & 0.23 \\
\hline 11 & Contract & 0.10 & 0.46 & 0.45 & 0.39 & 0.19 & 0.42 & 0.34 & 0.37 & 0.35 & 0.14 & 0.19 & 0.22 \\
\hline 12 & Cultural & 0.25 & 0.13 & 0.14 & 0.17 & 0.28 & 0.18 & 0.19 & 0.22 & 0.32 & 0.35 & 0.22 & 0.16 \\
\hline 13 & Econ & 0.20 & 0.23 & 0.25 & 0.27 & 0.17 & 0.30 & 0.21 & 0.28 & 0.27 & 0.19 & 0.31 & 0.15 \\
\hline 14 & Entrep & 0.19 & 0.19 & 0.19 & 0.23 & 0.19 & 0.22 & 0.26 & 0.20 & 0.23 & 0.20 & 0.41 & 0.20 \\
\hline 15 & Ethics & 0.23 & 0.24 & 0.29 & 0.17 & 0.34 & 0.27 & 0.24 & 0.30 & 0.38 & 0.39 & 0.22 & 0.27 \\
\hline 16 & $\mathrm{H} \& \mathrm{~S}$ & 0.19 & 0.29 & 0.27 & 0.23 & 0.30 & 0.30 & 0.30 & 0.32 & 0.34 & 0.28 & 0.16 & 0.23 \\
\hline 17 & $\mathrm{HR}$ & 0.20 & 0.22 & 0.21 & 0.29 & 0.20 & 0.21 & 0.28 & 0.26 & 0.19 & 0.15 & 0.33 & 0.26 \\
\hline 18 & Innov & 0.18 & 0.27 & 0.30 & 0.27 & 0.22 & 0.34 & 0.32 & 0.35 & 0.33 & 0.21 & 0.31 & 0.21 \\
\hline 19 & $\mathrm{KM}$ & 0.18 & 0.23 & 0.22 & 0.23 & 0.21 & 0.24 & 0.27 & 0.25 & 0.27 & 0.22 & 0.36 & 0.18 \\
\hline 20 & Law & 0.11 & 0.39 & 0.40 & 0.31 & 0.21 & 0.46 & 0.37 & 0.43 & 0.39 & 0.23 & 0.25 & 0.20 \\
\hline 21 & Market & 0.19 & 0.23 & 0.22 & 0.25 & 0.19 & 0.24 & 0.31 & 0.20 & 0.21 & 0.15 & 0.34 & 0.20 \\
\hline 22 & MotivLead & 0.33 & 0.16 & 0.15 & 0.19 & 0.21 & 0.16 & 0.19 & 0.17 & 0.16 & 0.21 & 0.27 & 0.40 \\
\hline 23 & NPV & 0.18 & 0.30 & 0.32 & 0.30 & 0.18 & 0.39 & 0.28 & 0.38 & 0.33 & 0.17 & 0.30 & 0.21 \\
\hline 24 & OrgStr & 0.23 & 0.23 & 0.24 & 0.30 & 0.21 & 0.25 & 0.33 & 0.26 & 0.24 & 0.21 & 0.35 & 0.21 \\
\hline 25 & Persnlty & 1.00 & 0.10 & 0.11 & 0.19 & 0.18 & 0.13 & 0.15 & 0.14 & 0.14 & 0.22 & 0.22 & 0.29 \\
\hline 26 & PM_Monit & 0.10 & 1.00 & 0.65 & 0.31 & 0.19 & 0.46 & 0.37 & 0.35 & 0.33 & 0.15 & 0.19 & 0.24 \\
\hline 27 & PM_Plan & 0.11 & 0.65 & 1.00 & 0.31 & 0.19 & 0.49 & 0.35 & 0.37 & 0.37 & 0.18 & 0.21 & 0.25 \\
\hline 28 & Procure & 0.19 & 0.31 & 0.31 & 1.00 & 0.17 & 0.31 & 0.31 & 0.33 & 0.26 & 0.18 & 0.27 & 0.22 \\
\hline 29 & ProfMemb & 0.18 & 0.19 & 0.19 & 0.17 & 1.00 & 0.20 & 0.22 & 0.21 & 0.24 & 0.38 & 0.18 & 0.23 \\
\hline 30 & ProjCost & 0.13 & 0.46 & 0.49 & 0.31 & 0.20 & 1.00 & 0.33 & 0.37 & 0.39 & 0.20 & 0.25 & 0.24 \\
\hline 31 & Quality & 0.15 & 0.37 & 0.35 & 0.31 & 0.22 & 0.33 & 1.00 & 0.35 & 0.32 & 0.18 & 0.28 & 0.21 \\
\hline 32 & RiskMan & 0.14 & 0.35 & 0.37 & 0.33 & 0.21 & 0.37 & 0.35 & 1.00 & 0.39 & 0.21 & 0.26 & 0.22 \\
\hline 33 & Enviro & 0.14 & 0.33 & 0.37 & 0.26 & 0.24 & 0.39 & 0.32 & 0.39 & 1.00 & 0.29 & 0.26 & 0.19 \\
\hline 34 & Society & 0.22 & 0.15 & 0.18 & 0.18 & 0.38 & 0.20 & 0.18 & 0.21 & 0.29 & 1.00 & 0.20 & 0.21 \\
\hline 35 & Strategy & 0.22 & 0.19 & 0.21 & 0.27 & 0.18 & 0.25 & 0.28 & 0.26 & 0.26 & 0.20 & 1.00 & 0.23 \\
\hline 36 & TeamDev & 0.29 & 0.24 & 0.25 & 0.22 & 0.23 & 0.24 & 0.21 & 0.22 & 0.19 & 0.21 & 0.23 & 1.00 \\
\hline
\end{tabular}

Table A2: Correlation matrix for the various topics.

\section{Association rules analysis for 'Communication' as the body}

\begin{tabular}{|l|l|l|l|l|l|l|}
\hline Rule & Body & $==>$ & Head & Support (\%) & $\begin{array}{l}\text { Confidence } \\
(\%)\end{array}$ & $\begin{array}{l}\text { Correlation } \\
(\%)\end{array}$ \\
\hline 57 & Communic & $==>$ & PM_Plan & 36.57143 & 74.75292 & 75.992 \\
\hline 58 & Communic & $==>$ & ProjCost & 30.59341 & 62.53369 & 69.50231 \\
\hline 62 & Communic & $==>$ & PM_Monit & 28.83516 & 58.9398 & 68.83529 \\
\hline 69 & Communic & $==>$ & PM_Plan, PM_Monit & 27.25275 & 55.7053 & 68.17885 \\
\hline 59 & Communic & $==>$ & Law & 27.07692 & 55.34591 & 65.98607 \\
\hline 65 & Communic & $==>$ & Ethic & 26.9011 & 54.98652 & 61.3529 \\
\hline 61 & Communic & $==>$ & Contract & 26.15385 & 53.45912 & 64.65127 \\
\hline 66 & Communic & $==>$ & PM_Plan, ProjCost & 25.97802 & 53.09973 & 67.05207 \\
\hline 56 & Communic & $==>$ & TeamDev & 23.38462 & 47.79874 & 55.35094 \\
\hline 60 & Communic & $==>$ & Enviro & 22.50549 & 46.0018 & 60.85466 \\
\hline
\end{tabular}




\begin{tabular}{|l|l|l|l|l|l|l|}
68 & Communic & $==>$ & PM_Plan, Contract & 22.32967 & 45.64241 & 61.95804 \\
\hline 67 & Communic & $==>$ & PM_Plan, Law & 22.28571 & 45.55256 & 62.61851 \\
\hline 64 & Communic & $==>$ & H\&S & 22.06593 & 45.10332 & 56.35226 \\
\hline 72 & Communic & $==>$ & ProjCost, PM_Monit & 21.75824 & 44.47439 & 62.25632 \\
\hline 70 & Communic & $==>$ & PM_Plan, Ethic & 21.71429 & 44.38455 & 61.16888 \\
\hline 55 & Communic & $==>$ & Work Activity == PlanDesign & 21.71429 & 44.38455 & 46.77842 \\
\hline 73 & Communic & $==>$ & PM_Plan, ProjCost, PM_Monit & 20.92308 & 42.7673 & 61.39917 \\
\hline 71 & Communic & $==>$ & ProjCost, Law & 20.65934 & 42.22821 & 60.01703 \\
\hline 63 & Communic & $==>$ & RiskMan & 20.35165 & 41.59928 & 56.51643 \\
\hline
\end{tabular}

Table A3: Association rules for 'communication' as the body. These show that many respondents who thought communication (body) was important also thought that various other topics were important. For example Rule 57 is that 37\% of respondents said that both communication and Project Planning were important. Furthermore, of those who identified Communication, 75\% also identified Project Planning. From this one infers that there is relatively strong association between these two topics.

Association rules for 'communication' as the head.

\begin{tabular}{|l|l|l|l|l|l|l|}
\hline Rule & Body & $==>$ & Head & Support(\%) & Confidence(\%) & Correlation(\%) \\
\hline & & & & & & \\
148 & PM_Plan, ProjCost, & $==>$ & Communic & 20.92308 & 88.14815 & 61.39917 \\
\hline 136 & ProjCost,PM_Monit & $==>$ & Communic & 21.75824 & 87.14789 & 62.25632 \\
\hline 111 & PM_Plan, Law & $==>$ & Communic & 22.28571 & 86.0781 & 62.61851 \\
\hline 129 & ProjCost, Law & $==>$ & Communic & 20.65934 & 85.29946 & 60.01703 \\
\hline 106 & PM_Plan, ProjCost & $==>$ & Communic & 25.97802 & 84.67049 & 67.05207 \\
\hline 127 & PM_Plan, Ethic & $==>$ & Communic & 21.71429 & 84.30034 & 61.16888 \\
\hline 120 & PM_Plan, Contract & $==>$ & Communic & 22.32967 & 84.10596 & 61.95804 \\
\hline 124 & PM_Plan, PM_Monit & $==>$ & Communic & 27.25275 & 83.44549 & 68.17885 \\
\hline 54 & Enviro & $==>$ & Communic & 22.50549 & 80.50314 & 60.85466 \\
\hline 85 & PM_Monit & $==>$ & Communic & 28.83516 & 80.39216 & 68.83529 \\
\hline 45 & Law & $==>$ & Communic & 27.07692 & 78.67178 & 65.98607 \\
\hline 77 & Contract & $==>$ & Communic & 26.15385 & 78.1866 & 64.65127 \\
\hline 12 & PM_Plan & $==>$ & Communic & 36.57143 & 77.25162 & 75.992 \\
\hline 32 & ProjCost & $==>$ & Communic & 30.59341 & 77.2475 & 69.50231 \\
\hline 94 & RiskMan & $==>$ & Communic & 20.35165 & 76.78275 & 56.51643 \\
\hline 96 & H\&S & $==>$ & Communic & 22.06593 & 70.40673 & 56.35226 \\
\hline 102 & Ethic & $==>$ & Communic & 26.9011 & 68.45638 & 61.3529 \\
\hline 5 & TeamDev & $==>$ & Communic & 23.38462 & 64.09639 & 55.35094 \\
\hline
\end{tabular}

Table A2: Association rules for 'communication' as the head.

\section{References}

1. IPENZ. (2009) Careers in Engineering. 200931 March 2015]; Available from: http://ipenz.org.nz/IPENZ/Career Development/Careers In Engineering.cfm.

2. IEM, (2013) Graduate Attributes and Professional Competencies International Engineering Alliance, http://www.washingtonaccord.org/GradProfiles.cfm(23 Nov 2013).

3. IPENZ. (2006) MANUAL FOR THE ACCREDITATION OF PROFESSIONAL ENGINEERING AND ENGINEERING TECHNOLOGY PROGRAMMES 200612 June 2009]; 5:[Available 
from: http://www.ipenz.org.nz/IPENZ/Forms/pdfs/Accreditation-Manual-5thEdition-November-06.pdf.

4. IPENZ. (2009) Requirements for Initial Academic Education for Professional Engineers 200912 June 2009]; Available from:

http://www.ipenz.org.nz/IPENZ/Forms/pdfs/Initial_Academic Policy Prof Eng.pdf.

5. de Swarte, T., (1998) Teaching European management to student business engineers. European Journal of Engineering Education, 23(4): p. 467-76.

6. Martin, R., Maytham, B., Case, J., and Fraser, D., (2005) Engineering graduates' perceptions of how well they were prepared for work in industry. European Journal of Engineering Education, 30(2): p. 167-80. DOI: 10.1080/03043790500087571.

7. Raine, J. K.,(1996) Undergraduate management teaching in mechanical engineering at the University of Canterbury, in Proceedings of Fifth Annual Engineering Management Educators Conference, "Shaping the Future of Engineering Management Education": Australian Graduate School of Engineering Innovation, Sydney.

8. Ward, R. B., (2003) Educating management: by case. World Transactions on Engineering and Technology Education, 2(2): p. 361-366.

9. Lyons, W. C., Anselmo, P. C., and Ruben, R. A.(1996) Industrial versus academic perceptions of the entry level engineering graduate. in Annual Meeting of the Decision Sciences Institute. Atlanta, GA, USA: Decis Sci Inst.

10. Lundquist, J., (1979) Management education in engineering. European Journal of Engineering Education, 4(1): p. 13-16.

11. Chi-Kuang, C., Jiang, B. C., and Kuang-Yiao, H., (2005) An empirical study of industrial engineering and management curriculum reform in fostering students' creativity. European Journal of Engineering Education, 30(2): p. 191-202. DOI: 10.1080/03043790500087423.

12. Faria, A. J. and Wellington, W. J., (2005) Validating business gaming: business game conformity with PIMS findings. Simulation \&amp; Gaming, 36(2): p. 259-73. DOI: 10.1177/1046878105275454.

13. Changa, Y. C., Peng, H. Y., and Chao, H. C., (2010) Examining the effects of learning motivation and of course design in an instructional simulation game. Interactive Learning Environments, 18(4): p. 319-39. DOI: 10.1080/10494820802574270.

14. Veshosky, D. and Egbers, J. H., (1991) Civil engineering project management game. Teaching with simulation. Journal of Professional Issues in Engineering Education and Practice, 117(3): p. 203-213.

15. Ravesteijn, W., De Graaff, E., and Kroesen, O., (2006) Engineering the future: the social necessity of communicative engineers. European Journal of Engineering Education, 31(1): p. 63-71. DOI: 10.1080/03043790500429005.

16. Dean, T. A., (1988) An undergraduate course in engineering, manufacture and management. European Journal of Engineering Education, 13(4): p. 391-7.

17. Kjersdam, F., (1993) Evaluation of project-organized engineering education. European Journal of Engineering Education, 18(4): p. 375-80.

18. Young, E. J.,(1978) The Evolution of the Management Engineer and Its Educational Implications, in Conference on Engineering Education (1978 : Sydney, N.S.W.)Institution of Engineers, Australia: Barton, ACT. 
19. Levy, J. and Dawkins, B., (1989) Continuing education and training (CET) and management and business skills for engineers. European Journal of Engineering Education, 14(1): p. 27-37.

20. Young, E. J.,(1982) Engineering Education and Career Patterns, in Conference on Engineering Education (1982 : Adelaide, S. Aust.)Institution of Engineers, Australia: Barton, ACT.

21. Young, E. J.,(1987) Engineering Management Education in Preparing Engineers for Leadership Roles in Australia, in Conference on Engineering Management (1987: Brisbane, Qld.)Institution of Engineers, Australia: Barton, ACT.

22. Young, E. J.,(1989) Developing Australian Engineers to be Engineering Leaders and Managers of Tomorrow, in Institution of Engineers, Australia. National Conference (1989 : Perth, W.A.)Institution of Engineers, Australia: Barton, ACT.

23. Young, E. J.,(1999) The New I.E. Aust Accreditation: Clarification or Confusion? - an Engineering Management Perspective, in Australasian Women in Engineering Forum (6th : 1999 : University of South Australia)University of South Australia: Adelaide, S. Aust.

24. Babcock, D. L.(1991) Past through tomorrow. Engineers, managers, and institutions. Barton, Aust: Publ by IE Aust.

25. IEM. (2007) INTERNATIONAL EDUCATIONAL ACCORDS: WASHINGTON ACCORD. 2007 7 Sept 2008]; Available from: http://www.ieagreements.com/Rules-and-ProceduresAug-2007.pdf or http://www.ieagreements.com/IEM Grad AttrProf Competencies v11(2).pdf.

26. ABET. (2011) Criteria for Accrediting Engineering Programs, 2010-2011 Review Cycle 201116 August 2011]; Available from: http://www.abet.org/forms.shtml.

27. Solem, O. and Young, E. J.(1999) Developments and trends in engineering management education in Australia and New Zealand in the nineties and trends towards the third millennium. in Portland International Conference on Management of Engineering and Technology. Portland, OR, USA: Portland Int. Conf. Manage. Eng. \&amp; Technol. PICMET.

28. Banik, G.(2008) Industry expectations from new construction engineers and managers: Curriculum improvement. in ASEE American Society for Engineering Education. Chantilly, VA 20153, United States: American Society for Engineering Education.

29. Karunes, S., (1988) Management training of engineering students at the Indian Institute of Technology, Delhi. European Journal of Engineering Education, 13(4): p. 399-409.

30. Alberti, N., Di Maio, B., Noto La Diega, S., and Brandolese, A., (1988) Italian university opens to management engineering. European Journal of Engineering Education, 13(4): p. 411-14.

31. Ratchev, S., Blackwell, R., and Bonney, M., (2002) Design of an industrial management course: bringing together engineering and educational approaches. European Journal of Engineering Education, 27(1): p. 113-29. DOI: 10.1080/03043790110100164.

32. Cleary, D. B. and Sun, C. C., (2003) Course in professional practice issues. Journal of Professional Issues in Engineering Education and Practice, 129(1): p. 52-57. DOI: 10.1061/(ASCE)1052-3928(2003)129:1(52). 
33. Raper, S. A.(2002) Engineering management at UMR - Alumni voices. in ASEE Annual Conference. Washington, DC 20036, United States: American Society for Engineering Education.

34. Becerra-Fernandez, I., Lee, T., and Hopkins, G.(1998) Reaching out to engineering management students. in ASEE Conference. Washington, DC, USA: ASEE.

35. Bowen, D., Ganjeizadah, F., Motavalli, S., and Zong, H.(2005) Development of a new M.S. Degree in engineering management. in ASEE Conference. Chantilly, VA 20153, United States: American Society for Engineering Education.

36. Joshi, G.(2004) Development of engineering management course at southern university. in ASEE Annual Conference. Washington, DC 20036, United States: American Society for Engineering.

37. Lewis Jr, V. W. and Kauffmann, P.(2002) Enhancement of a civil engineering technology curriculum by the addition of a minor in engineering management. in ASEE Annual Conference. Washington, DC 20036, United States: American Society for Engineering Education.

38. Ladd, E. R., Holt, J. R., and Rumsey, H. A.(2001) The engineering management program at Washington state university: Distance education industry partnership success stories. in ASEE Annual Conference. Washington, DC 20036, United States: American Society for Engineering Education.

39. Merino, D. N.(2000) Executive level masters programs in technology management (TM), management of technology (MoT) and engineering management (EM). in ASEE Annual Conference. Washington, DC 20036, United States: American Society for Engineering Education.

40. Mallick, D. N. and Chaudhury, A., (2000) Technology management education in MBA programs: A comparative study of knowledge and skill requirements. Journal of Engineering and Technology Management - JET-M, 17(2): p. 153-173.

41. Sun, H., Yam, R. C. M., and Venuvinod, P. K., (1999) Education in engineering management. Journal of Engineering Education, 88(2): p. 181-184.

42. Beruvides, M. G. and James, M. R.(1997) Perceptions from the trenches: Engineering management vs. MBA. in ASEE Conference. Washington, DC, USA: ASEE.

43. Mingers, J., (1991) Content of MSc Operational Research courses. Results of a questionnaire to OR groups. Journal of the Operational Research Society, 42(5): $p$. 375-382.

44. Raine, J. K.(1996) Undergraduate management teaching in mechanical engineering at the University of Canterbury. in Proceedings of Fifth Annual Engineering Management Educators Conference, "Shaping the Future of Engineering Management Education". Australian Graduate School of Engineering Innovation, Sydney.

45. Heaton, A. E., (1993) Meeting the real needs of European industry in Technology Management education and training. International Journal of Continuing Engineering Education, 3(1-2): p. 3-16.

46. Beck, H., (1979) Engineers and their perceptions of managers and management studies. European Journal of Engineering Education, 4(1): p. 3-12.

47. Farr, J. V. and Bowman, B. A., (1999) ABET accreditation of engineering management programs: contemporary and future issues. Engineering Management Journal, 11(4): p. 7-13. 
48. Furterer, S., Jenness, J., Steinberg, J., Crumpton-Young, L., Williams, K., and Rabelo, L.(2006) Experiential learning for industrial engineering curriculum. in ASEE Conference. Chantilly, VA 20153, United States: American Society for Engineering Education.

49. Waks, S. and Frank, M., (2000) Engineering curriculum versus industry needs-a case study. IEEE Transactions on Education, 43(3): p. 349-52.

50. Marin-Garcia, J. A. and Lloret, J., (2011) Industrial engineering higher education in the European area (EHEA). Journal of Industrial Engineering and Management, 4(1): p. 1-12. DOI: 10.3926/jiem.2011.v4n1.p1-12.

51. Chan, E. H. W., Scott, D., Chan, A. T. S., and Chan, M. W., (2002) Educating the 21st century construction professionals. Journal of Professional Issues in Engineering Education and Practice, 128(1): p. 44-51.

52. King, M. C., (1988) Interdisciplinarity and systems thinking: some implications for engineering education and education for industry. European Journal of Engineering Education, 13(3): p. 235-44.

53. Palmer, S., (2003) Framework for undergraduate engineering management studies. Journal of Professional Issues in Engineering Education and Practice, 129(2): p. 92-99.

54. Merino, D. N.(2000) Impact of ABET 2000 on teaching engineering economics: What subjects define economic literacy for engineers? in ASEE Annual Conference. Washington, DC 20036, United States: American Society for Engineering Education.

55. Rammant, J. P., (1988) Why is marketing education a must for engineers? A manager's viewpoint. European Journal of Engineering Education, 13(4): p. 439-45.

56. Zandvoort, H., (2008) Preparing engineers for social responsibility. European Journal of Engineering Education, 33(2): p. 133-40.

57. Meyers, F. D., Fentiman, A. W., and Britton, R. R.(1993) The engineering core courses: are they preparing students for the future? in First International Conference on Graphics Education. Lisbon, Portugal: Tech. Univ. Lisbon.

58. Lappalainen, P., (2009) Communication as part of the engineering skills set. European Journal of Engineering Education, 34(2): p. 123-9. DOI: 10.1080/03043790902752038.

59. ASME, (2010) Guide to the engineering management body of knowledge, Edited. New York: ASME. IS BN 978-0-7918-0299-1

60. Railton, D., (1986) COMMUNICATION SKILLS TRAINING FOR ENGINEERING STUDENTS IN BRITISH UNIVERSITIES. IEEE Transactions on Professional Communications, PC29(2): p. 7-14.

61. Smith, E. D., (1948) Education of professional students for citizenship. Mechanical Engineering, 70(12): p. 959-962.

62. Bowron, P., (1990) Teaching communication skills in electrical engineering degree courses. International Journal of Electrical Engineering Education, 27(1): p. 3-12.

63. Bakos, J. D., Jr., (1997) Communication skills for the 21st century. Journal of Professional Issues in Engineering Education and Practice, 123(1): p. 14-16. DOI: 10.1061/(ASCE)1052-3928(1997)123:1(14).

64. Bonk, R. J., Imhoff, P. T., and Cheng, A. H. D., (2002) Integrating written communication within engineering curricula. Journal of Professional Issues in Engineering Education and Practice, 128(4): p. 152-159. DOI: 10.1061/(ASCE)10523928(2002)128:4(152). 
65. Jennings, A. and Ferguson, J. D., (1996) Integrating communication skills into civil engineering education. Proceedings of the Institution of Civil Engineers: Civil Engineering, 114(2): p. 73-80.

66. Mobrand, K. A., Turns, J., and Mobrand, L. M.(2013) Revealing and enhancing engineering undergraduate students' motivation for the communication of professional practice through creation of communication preparedness portfolios in a studio setting. in 2013 IEEE International Professional Communication Conference, IPCC 2013, July 15, 2013 - July 17, 2013. Vancouver, BC, Canada: Institute of Electrical and Electronics Engineers Inc.

67. Nylen, A. and Pears, A.(2013) Professional communication skills for engineering professionals. in 43rd IEEE Annual Frontiers in Education Conference, FIE 2013, October 23, 2013 - October 26, 2013. Oklahoma City, OK, United states: Institute of Electrical and Electronics Engineers Inc.

68. Prausnitz, M. R. and Bradley, M. J., (2000) Effective communication for professional engineering beyond problem sets and lab reports. Chemical Engineering Education, 34(3): p. 234-237.

69. Roeckel, M., Parra, E., Donoso, C., Mora, O., and Garcia, X., (2004) An innovative method for developing communication skills in engineering students. Chemical Engineering Education, 38(4): p. 302-307.

70. Tan, C. W. and LeMee, J. M., (1985) PROFESSIONAL COMPETENCE DEVELOPMENT IN ENGINEERING EDUCATION. The International journal of applied engineering education, 1(4): p. 253-258.

71. Trent Jr, J. L. and Todd, R. H., (2014) Bridging capstone design with industry needs through communication, training and involvement. International Journal of Engineering Education, 30(1): p. 14-19.

72. Wilson, J. C., (1995) Professional liaison program in undergraduate civil engineering. Journal of Professional Issues in Engineering Education and Practice, 121(3): p. 165169. DOI: 10.1061/(ASCE)1052-3928(1995)121:3(165).

73. Bish, A. J., Newton, C. J., Browning, V., O'Connor, P., and Anibaldi, R., (2014) An exploration of the professional competencies required in engineering asset management. European Journal of Engineering Education, 39(4): p. 432-447. DOI: 10.1080/03043797.2014.895701.

74. Bjeki, M., Bjeki, D., and Zlati, L., (2015) Communication competence of practicing engineers and engineering students: Education and evaluation. International Journal of Engineering Education, 31(1): p. 368-376.

75. Gilleard, J. and Gilleard, J. D., (2002) Developing cross-cultural communication skills. Journal of Professional Issues in Engineering Education and Practice, 128(4): p. 187200. DOI: 10.1061/(ASCE)1052-3928(2002)128:4(187).

76. May, D. and Tekkaya, A. E.(2015) The globally competent engineer: What different stakeholders say about educating engineers for a globalized world. in 2014 International Conference on Interactive Collaborative Learning, ICL 2014, December 3, 2014 - December 6, 2014. Dubai, United arab emirates: Institute of Electrical and Electronics Engineers Inc.

77. Gilbuena, D. M., Sherrett, B. U., Gummer, E. S., Champagne, A. B., and Koretsky, M. D., (2015) Feedback on professional skills as enculturation into communities of practice. Journal of Engineering Education, 104(1): p. 7-34. DOI: 10.1002/jee.20061. 
78. PMI, (2008) A guide to the project management body of knowledge (PMBOK guide) 4ed, Edited. 14 Campus Blvd, Newtown Square, Pennsylvania, USA: Project Management Institute. IS BN 978-1-933890-51-7

79. ISO 31000,(2009) Risk management -- Principles and guidelines International Organization for Standardization.

80. Al-Buraey, M. A. and Ghani, J. A., (1986) Management education for engineers: the case of Saudi Arabia. European Journal of Engineering Education, 11(4): p. 437-50.

81. IEM. (2009) Graduate Attributes and Professional Competencies. 200923 Nov 2009]; Version 2 - 18 June 2009:[Available from:

http://www.washingtonaccord.org/IEA-Grad-Attr-Prof-Competencies-v2.pdf. 